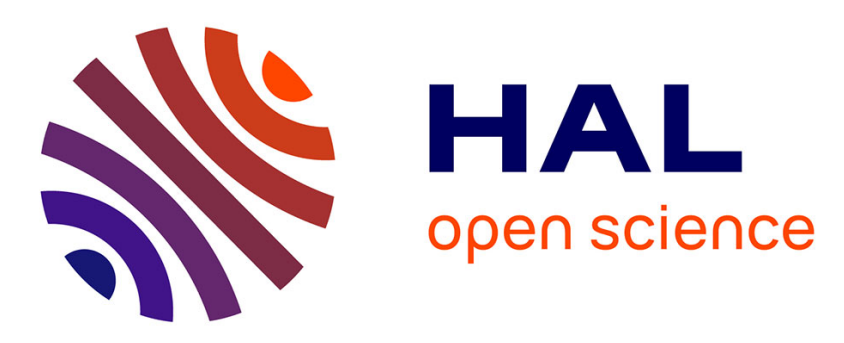

\title{
On the dynamics in the southeastern Ligurian Sea in summer 2010
}

Pierre-Marie Poulain, Elena Mauri, R. Gerin, Jacopo Chiggiato, Katrin

Schroeder, Annalisa Griffa, M. Borghini, E. Zambianchi, P. Falco, Pierre

Testor, et al.

\section{To cite this version:}

Pierre-Marie Poulain, Elena Mauri, R. Gerin, Jacopo Chiggiato, Katrin Schroeder, et al.. On the dynamics in the southeastern Ligurian Sea in summer 2010. Continental Shelf Research, 2020, 196, pp.104083. 10.1016/j.csr.2020.104083 . hal-02904210

\section{HAL Id: hal-02904210 https://hal.science/hal-02904210}

Submitted on 9 Dec 2020

HAL is a multi-disciplinary open access archive for the deposit and dissemination of scientific research documents, whether they are published or not. The documents may come from teaching and research institutions in France or abroad, or from public or private research centers.
L'archive ouverte pluridisciplinaire HAL, est destinée au dépôt et à la diffusion de documents scientifiques de niveau recherche, publiés ou non, émanant des établissements d'enseignement et de recherche français ou étrangers, des laboratoires publics ou privés. 


\section{Continental Shelf Research \\ On the dynamics in the southeastern Ligurian Sea in summer 2010 --Manuscript Draft--}

\begin{tabular}{|c|c|}
\hline \multicolumn{2}{|l|}{ Manuscript Number: } \\
\hline Article Type: & Research paper \\
\hline Section/Category: & $\begin{array}{l}\text { Physical Oceanography (estuarine, coastal and shelf sea - modelling and process } \\
\text { studies) }\end{array}$ \\
\hline Keywords: & $\begin{array}{l}\text { Drifter, glider, Ligurian Sea, Corsica Channel, offshore-flowing filaments, wind-driven } \\
\text { circulation }\end{array}$ \\
\hline Corresponding Author: & $\begin{array}{l}\text { Pierre-Marie Poulain } \\
\text { OGS } \\
\text { Sgonico, Trieste Italy }\end{array}$ \\
\hline First Author: & Pierre-Marie Poulain \\
\hline \multirow[t]{11}{*}{ Order of Authors: } & Pierre-Marie Poulain \\
\hline & Elena Mauri \\
\hline & Riccardo Gerin \\
\hline & Jacopo Chiggiato \\
\hline & Katrin Schroeder \\
\hline & Annalisa Griffa \\
\hline & Mireno Borghini \\
\hline & Enrico Zambianchi \\
\hline & Pier Paolo Falco \\
\hline & Pierre Testor \\
\hline & Laurent Mortier \\
\hline Abstract: & $\begin{array}{l}\text { Drifters and a glider were operated in the southeastern Ligurian Sea to study the near- } \\
\text { surface currents and water mass properties in summer 2010. Additional data were } \\
\text { collected by a moored current meter in the Corsica Channel (CC). These in situ data } \\
\text { were complemented by surface wind products, satellite images of chlorophyll } \\
\text { concentration and a Regional Ocean Modeling System (ROMS) numerical model that } \\
\text { was implemented to simulate the local coastal dynamics. Southward currents were } \\
\text { prevailing along the continental Italian coast, advecting filaments with a high optical } \\
\text { signal coming from the Arno River. North of Elba Island, currents turned westward and } \\
\text { northward in the vicinity of the CC. Further to the north they veered eastward, forming } \\
\text { an anticyclonic circulation feature centered around Capraia Island. This general } \\
\text { circulation picture was disrupted and reversed during events of sustained southerly } \\
\text { winds occurring with a period of about a week. The near-surface currents in the CC } \\
\text { and the anticyclonic circulation around Capraia Island showed the same weekly } \\
\text { variations related to the local wind forcing. The ROMS model simulations agreed } \\
\text { satisfactorily with the observations, in particular the strength of the Capraia anticyclonic } \\
\text { circulation (quantified with the Capraia index) was confirmed to be strongly wind- } \\
\text { dependent. }\end{array}$ \\
\hline \multirow[t]{4}{*}{ Suggested Reviewers: } & $\begin{array}{l}\text { Hezi Gildor } \\
\text { hezi.gildor@mail.huji.ac.il }\end{array}$ \\
\hline & $\begin{array}{l}\text { Dan Hayes } \\
\text { hayesdan@cyprus-subsea.com }\end{array}$ \\
\hline & $\begin{array}{l}\text { Nadia Pinardi } \\
\text { nadia.pinardi@unibo.it }\end{array}$ \\
\hline & $\begin{array}{l}\text { Carlo Brandini } \\
\text { brandini@lamma.rete.toscana.it }\end{array}$ \\
\hline
\end{tabular}


Dear Sir/Madam:

Please find attached a manuscript entitled "On the dynamics in the southeastern Ligurian Sea in summer 2010" that we would like to be considered for publication in the Continental Shelf Research.

Sincerely yours.

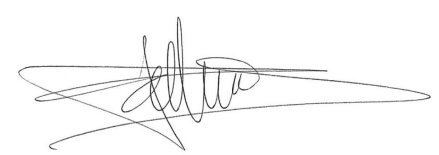

Dr. Pierre-Marie Poulain

Head, Mobile Autonomous Oceanographic Systems (MAOS)

Oceanography Section, OGS

Senior Scientist

Environmental Knowledge and Operational Effectiveness (EKOE), CMRE 
On the dynamics in the southeastern Ligurian Sea in summer 2010

${ }^{1,2}$ Poulain P.-M, ${ }^{1}$ Mauri E., ${ }^{1}$ Gerin R., ${ }^{3}$ Chiggiato J., ${ }^{3}$ Schroeder K., ${ }^{4}$ Griffa A., ${ }^{4}$ Borghini M., ${ }^{5,6}$ Zambianchi E., ${ }^{5}$ Falco P., ${ }^{7}$ Testor P., ${ }^{7}$ Mortier L.

17 Corresponding author:

18 P.-M. Poulain,

19 OGS, Borgo Grotta Gigante, 40/c,

20 Sgonico (TS), Italy

21 (ppoulain@inogs.it)

Keywords: Drifter, glider, Ligurian Sea, Corsica Channel, offshore-flowing filaments, 
30

31 - The surface circulation in the southeastern Ligurian Sea is strongly winddependent.

33

- Anticyclonic circulation around Capraia Island is predominant.

34

- Currents transport offshore filaments of low-salinity and nutrient-rich waters of riverine origin. 
Drifters and a glider were operated in the southeastern Ligurian Sea to study the near-

39 surface currents and water mass properties in summer 2010. Additional data were collected by

40 a moored current meter in the Corsica Channel (CC). These in situ data were complemented

41 by surface wind products, satellite images of chlorophyll concentration and a Regional Ocean

42 Modeling System (ROMS) numerical model that was implemented to simulate the local

43 coastal dynamics. Southward currents were prevailing along the continental Italian coast,

44 advecting filaments with a high optical signal coming from the Arno River. North of Elba

45 Island, currents turned westward and northward in the vicinity of the CC. Further to the north

46 they veered eastward, forming an anticyclonic circulation feature centered around Capraia

47 Island. This general circulation picture was disrupted and reversed during events of sustained

48 southerly winds occurring with a period of about a week. The near-surface currents in the CC

49 and the anticyclonic circulation around Capraia Island showed the same weekly variations

50 related to the local wind forcing. The ROMS model simulations agreed satisfactorily with the

51 observations, in particular the strength of the Capraia anticyclonic circulation (quantified with

52 the Capraia index) was confirmed to be strongly wind-dependent. 
55 Currents and transports of water mass properties in sea areas including islands and channels

56 and in the coastal zone are crucial at the local scale for the dispersion and mixing of pollutants

57 and at the large scale for the interaction between different basins, which in turn can control

58 the whole functioning of entire seas or oceans. Besides, if important river mouths co-exist in

59 the vicinity of islands and channels, the distribution of the water masses and the local

60 ecosystem dynamics can even be more complex and challenging to monitor and study.

61

62 The Mediterranean area in the southeastern Ligurian Sea and northern Tyrrhenian Sea (Fig.

63 1), connected by the Corsica Channel (CC), is such an area, with complex topography and 64 coast morphology, the existence of several islands (Elba, Monte Cristo, Giglio, etc) and also

65 the mouth of an important Italian river (the Arno River). Fluxes across the CC have been 66 measured almost continuously between 1982 and 1998 with moored currentmeters (Manzella,

67 1984; Astraldi et al., 1990; Astraldi and Gasparini, 1992). The northward flowing current in 68 the CC, also referred to as the Tyrrhenian (Astraldi and Gasparini, 1992) or Eastern Corsica 69 Current (ECC, Pinardi et al. 2006), is maximum in winter and is mainly driven by the steric 70 sea level difference between the Tyrrhenian to the south and the Ligurian Sea to the north. 71 This difference is larger in winter due to the larger heat loss and the local effect of the wind 72 stress curl in the Liguro-Provençal basin (Pinardi and Masetti, 2000). The heat flux 73 associated with the ECC varies seasonally and plays a crucial role for deep water formation 74 processes in the NW Mediterranean (Astraldi and Gasparini, 1992). The ECC is characterized 75 by velocity fluctuations with periods between 2 and 15 days with the occurrence of 76 intermittent reversals (Astraldi et al., 1990).

78 This ECC seasonal (and also inter-annual) variability was confirmed by satellite altimetry 79 data along selected satellite sub-tracks criss-crossing in the CC vicinity (Vignudelli et al., 
80 1999, 2000, 2005; Bouffard et al., 2008). Vignudelli et al. (1999) have shown that the

81 interannual variations of water transport through the $\mathrm{CC}$, as measured by satellite altimeters,

82 can be related to the North Atlantic Oscillation. More recently, Bouffard et al. (2008) have

83 demonstrated that multi-mission altimetric data agree well with in-situ measurements and

84 therefore represent an accurate long-term mean to monitor the exchange between the

85 Tyrrhenian and Ligurian seas.

87 Conductivity-temperature-depth (CTD) measurements and numerical simulations (Onken et 88 al., 2005) as well as surface drifters (Poulain et al., 2012) have shown that the ECC can veer 89 in the clockwise sense around Capraia Island and form an anticyclonic eddy centered around 90 the island. We will refer to this circulation feature as the Capraia anticyclone, although it has 91 recently been also named "Ligurian Anticyclone" by Ciuffardi et al. (2016). It appears to be

92 dominant in summer when the ECC is weak. In particular, one drifter in summer 2007 93 completed 5 full loops around the island with a periodicity of about 3 days (Poulain et al., 94 2012).

96 In this paper, simultaneous observations of currents and water mass properties obtained by a 97 glider, surface drifters and moored instruments, along with ancillary satellite data and wind 98 products and numerical model simulations, are used to explore and study the dynamics of the 99 southeastern Ligurian and CC in summer 2010. Most data were collected as part of the 100 LIDEX10 campaign, whose general objective was to improve the understanding of turbulent 101 transport and dispersion in the ocean, more specifically to study the dispersion in a coastal 102 frontal zone due to mixing by meso- and submesoscale structures (Schroeder et al., 2012). 103 The main focus of this paper is on mesoscale $(\sim 10 \mathrm{~km})$ and submesoscale $(<10 \mathrm{~km})$ 104 structures, some of them transporting offshore and mixing the fresh and nutrient-rich waters 105 of river origin. The Capraia anticyclone, which has a subbasin scale $(40-50 \mathrm{~km})$, is described 
106 quantitatively using the drifter data. Some aspects of the near-surface circulation and ECC

107 transport are also investigated, relating them to the local wind forcing.

109 Details about the instruments used and the collected data are provided in section 2. The

110 surface circulation as measured by the drifters is described in section 3.1, including a

111 qualitative description of their motions and a quantitative study of the Capraia anticyclone.

112 The effect of the local wind forcing is explored in section 3.2, using both observations and

113 numerical simulations obtained with the Regional Ocean Modelling System (ROMS). The

114 surface circulation derived from ocean color satellite images superimposed with drifter tracks

115 is discussed in section 3.3. Section 3.4 includes the results on the 3D spatial structure and

116 temporal evolution of the water mass properties (temperature and salinity) provided by the

117 glider and also detected in ocean color satellite images. Discussion of the most salient results

118 and conclusions are found in section 4.

120 2. Data and methods

121 The LIDEX10 experiment took place on-board the R/V Maria Grazia of the Italian National 122 Research Council (CNR) on 3 July 2010 in the southeastern Ligurian Sea off the Tuscany 123 coast (Italy). First, a conductivity-temperature-depth (CTD) survey was carried on, along a 124 zonal transect at latitude $43^{\circ} 35.34^{\prime} \mathrm{N}$ and between longitudes $9^{\circ} 56.7^{\prime} \mathrm{E}$ and $10^{\circ} 5.94^{\prime} \mathrm{E}$, 125 including 12 casts down to $50 \mathrm{~m}$ depth and separated by 1-4 $\mathrm{km}$. The CTD data revealed a 126 near-surface vertical front in the top 7-8 $\mathrm{m}$ below the surface, separating lower salinity and 127 higher chlorophyll fluorescence water inshore from saltier and poorer water offshore 128 (Schroeder et al., 2012). The CTD data are not discussed any further in this paper since the 129 glider repeated the same transect shortly after. 


\subsubsection{Drifters}

134 Two groups of 9 drifters were deployed after the CTD transect on 3 July 2010, on each side of 135 the front, approximately $5 \mathrm{~km}$ apart. For each group, the drifters were released in three tight 136 triplets separated by 300-500 m, and with 50-100 m distance between the drifters within each 137 triplet (see Fig. 2 of Schroeder et al., 2012). An additional drifter was deployed between the 2 138 groups on the front. In brief, the 19 drifters were deployed with relative distances ranging 139 from $50 \mathrm{~m}$ to $6 \mathrm{~km}$. The deployments were conducted in less than $4 \mathrm{~h}$ (from 11:34 to 15:26 140 GMT). All drifters were CODE designs (Poulain, 1999; Poulain and Gerin, 2019), fitted with 141 GPS receivers and manufactured by Technocean (Cape Coral, Florida). They measure the 142 currents in the top first meter below the surface with an accuracy of $1-2 \mathrm{~cm} / \mathrm{s}$. The principal 143 error is a wind-induced slip of about $0.1 \%$ of the wind speed (Poulain and Gerin, 2019). Most 144 of the drifters (17 units) transmitted their data to the Argos system on-board polar-orbiting 145 satellites, whereas 2 drifters used the Iridium telemetry system. GPS positions and ancillary 146 data (e.g., sea surface temperature, battery voltage) were transmitted every hour.

148 The drifter GPS data were quality controlled and interpolated at $0.5 \mathrm{~h}$ intervals using a kriging 149 technique (see Menna et al., 2017 and references therein). Velocities were calculated by finite 150 differencing the interpolated positions (central difference scheme with hourly interval). For 151 some applications (see section 3.2) the drifter velocity timeseries were low-pass filtered with a 152 Hamming filter $(36 \mathrm{~h})$ to remove high frequency motions.

154 The mean half-life of the 19 drifters deployed on 3 July 2010 is about 2 weeks (many drifters 155 stopped on 19-21 July after 16-18 days). Unfortunately, the single drifter deployed between 156 the two clusters was rather short lived and stopped functioning on 7 July. 


\subsubsection{Glider}

159 A shallow water Slocum glider manufactured by Teledyne Webb Research, Falmouth,

160 Massachussetts was deployed at location $43^{\circ} 35.78^{\prime} \mathrm{N}, 10^{\circ} 06.20^{\prime}$ E on 3 July 2010 , shortly

161 after the drifter deployments (i.e., at 16:29 GMT). The glider was equipped with an un162 pumped Sea-Bird Scientific SBE $41 \mathrm{CT}$ to measure conductivity $(0.0003 \mathrm{~S} / \mathrm{m})$, temperature $163\left(0.002{ }^{\circ} \mathrm{C}\right)$ and pressure $(0.5 \mathrm{psi})$, along with sensors to measure dissolved oxygen, particle 164 backscattering and coloured dissolved organic matter fluorescence. It was programmed to 165 measure vertical properties of the water column as deep as $200 \mathrm{~m}$. All sensors were set to 166 record every 8 seconds. The typical horizontal resolution of the glider data along its route was 167 about $0.5 \mathrm{~km}$. In this paper only temperature, salinity and density observations are considered 168 to describe the local dynamics, with a main focus on the top $40 \mathrm{~m}$ of water.

170 The glider was initially piloted to sample the transect surveyed by the research vessel. Given

171 the southward motion of the drifters, and in order to have the glider and drifters in the same 172 area at about the same time, the glider was subsequently programmed to survey the 173 southeastern Ligurian Sea in a southward zig-zag pattern until it approached the northern 174 coast of Elba Island (Fig. 1). At this point it was piloted to move westward and to sample the $175 \mathrm{CC}$, until it was recovered on 20 July 2010 (at about 10:00 GMT) at $43^{\circ} 00.90^{\prime} \mathrm{N}, 09^{\circ} 35.82^{\prime}$ 176 E, between the northern tip of Corsica and Capraia Island.

179 A mooring with current meters is maintained by CNR ISMAR in the CC (between the 180 northern tip of Corsica and Capraia Island) since 1985 . Its location is $43^{\circ} 1.5^{\prime} \mathrm{N}, 9^{\circ} 41.0^{\prime} \mathrm{E}$. 181 Current profiles are measured with an upward $75 \mathrm{KHz}$ RDI Acoustic Dopler Current Profiler 182 (ADCP), with a bin size of $16 \mathrm{~m}$, between 32 and $384 \mathrm{~m}$ at $2 \mathrm{~h}$ intervals. The meridional and 
183 zonal velocities were extracted from the dataset for the period July-August 2010. Only the 184 meridional (along-channel) component is considered here, since it is more significant for our 185 scopes than the zonal (across-channel) component (the meridional speed is on average 3 times 186 stronger than the zonal one), and gives indication on the water exchange between the 187 Tyrrhenian and the Ligurian Sea. For comparison with the surface drifter data, the mooring 188 data near $32 \mathrm{~m}$ depth was considered. In order to remove high frequency fluctuations, a 189 Hamming filter with cut off period of $36 \mathrm{~h}$ was applied to the velocity time series.

\subsection{Remotely sensed data}

192 Moderate Resolution Imaging Spectroradiometer (MODIS) satellite images of chlorophyll 193 concentration of the study area were used to describe the spatial structure and temporal 194 evolution of the surface circulation assuming that chlorophyll is a passive tracer advected by 195 the surface horizontal currents. Images of chlorophyll concentration were preferred on sea 196 surface temperature images as they delineate better the circulation features at meso- and 197 submesoscales (better contrast). Being in a coastal area where a river outflows nutrient-rich 198 water, there is a sharp contrast between coastal and offshore waters, the former being richer 199 (higher chlorophyll) and slightly colder (by about $1{ }^{\circ} \mathrm{C}$, in our case). The daily images have a 200 horizontal resolution of $1 \mathrm{~km}$.

\subsection{Wind products}

203 Consortium for Small-scale Modeling (COSMO, http://www.cosmo-model.org) wind 204 products run by the Italian Air Force National Meteorological Center were obtained for the 205 study area in July and August 2010. In particular, the COSMO-ME gridded 10-m vector 206 winds with $7 \mathrm{~km}$ grid spacing were used to force the ROMS model and to relate the wind 207 forcing to the currents measured by the drifters and at the $\mathrm{CC}$ mooring. For some applications 208 (see section 3.2) the COSMO-ME wind velocity timeseries were also low-pass filtered with a 
209 Hamming filter $(36 \mathrm{~h})$ to remove high frequency fluctuations. Wind data at $10-\mathrm{m}$ were also

210 obtained from the ODAS buoy (also called W1-M3A) located in the central Ligurian Sea (43

$\left.21148^{\prime} \mathrm{N}, 9^{\circ} 9.6^{\prime} \mathrm{E}\right)$.

212

213

\subsection{Numerical simulations}

214 The ocean model employed in this application is the ROMS (Haidvogel et al., 2008;

215 Shchepetkin and McWilliams, 2005). As part of LIDEX10, the model was set up in

216 operational forecast mode on a domain covering the entire Ligurian Sea. The horizontal

217 resolution is $2 \mathrm{~km}$, with 32 vertical sigma-levels non-linearly stretched to resolve the surface

218 boundary layer. The ocean model was forced by the COSMO-ME 10-m winds. Open

219 boundary conditions were applied to tracers and baroclinic velocity with radiation and

220 nudging (Marchesiello et al. 2001) from daily averages of the large-scale Mediterranean

221 Forecasting System (MFS) forecasts (Oddo et al., 2009). Three major rivers were included:

222 the Arno (daily discharges), Serchio and Magra (monthly climatologies). The operational

223 ROMS-based system was initialized on 1 May 2010 using an analysis field from the

224 Mediterranean Forecasting System (MFS) model. Since then, ROMS was run in forecast 225 mode once a day (00:00 UTC) with output data every $3 \mathrm{~h}$ and forecast range of $72 \mathrm{~h}$. Data 226 assimilative analysis fields from the forecast system are available in Mourre and Chiggiato

227 (2014), but just for a short period. Thus, for this work only the free run (i.e., without data 228 assimilation) is considered. Additional details on the physics and numerical details

229 implemented in this application and performance can be found in Alvarez et al. (2012), 230 Schroeder et al. (2012), Mourre et al. (2011) and Mourre and Chiggiato (2014).

232 3. Results

$233 \quad 3.1$ Surface circulation 
235 After deployment, all drifters moved southward, with the coastal group (red tracks in Fig. 2) 236 going faster and reaching $43^{\circ} \mathrm{N}$ latitude after 4 days, on 7 July. The other group (blue tracks in

237 Fig. 2) followed with about 1-day delay. Between 7 and 10 July the coastal group proceeded 238 westward towards the $\mathrm{CC}$, and veered southward upon approaching Corsica. In contrast, the 239 other drifters slowed down and stagnated just north of Elba Island for about 2 days (11-12 240 July). Most of these drifters then moved northward (in the ECC and also near the Italian 241 continental coast) on 13-14 July, before turning back and moving south and west starting on 24215 July. On 15-19 July, the drifters in the southern part of the CC showed slow and rather 243 chaotic currents, except for 2 drifters which moved swiftly northward between the northern tip 244 of Corsica and Capraia Island on 14 and 19 July. Four drifters (blue tracks) moved to the 245 southwest rapidly on 19 July and joined the area of the CC.

247 After the recovery of the glider on 20 July, some drifters continued to provide data on the 248 surface circulation in the study area for about another month (not shown). The most striking 249 characteristics of the currents during that period are: 1) on 22 July, fast northward currents in 250 the CC; 2) on 23-25 July, reversal of this current with drifter moving south in the CC; and 3) a 251 prevailing anticyclonic circulation around Capraia Island mostly during the period 20 July 25217 August. No drifter moved north of $43^{\circ} 30^{\prime} \mathrm{N}$ and only 3 drifters moved eventually to the 253 Tyrrhenian Sea south of $42^{\circ} 30^{\prime} \mathrm{N}$ after some time. The composite plot of all the drifter 254 trajectories between 3 July and 27 August 2010 is shown in Fig. 3, with speed color-coded 255 along the trajectories. Fastest unfiltered currents reaching $90 \mathrm{~cm} / \mathrm{s}$ occur north of the CC in 256 the ECC (near $43^{\circ} 15^{\prime} \mathrm{N}$ ). Southward currents sampled during the first few days after 257 deployment range in $30-40 \mathrm{~cm} / \mathrm{s}$. Currents in the anticyclonic circulation around Capraia 258 Island are mostly in the $30-60 \mathrm{~cm} / \mathrm{s}$ range. In the "stagnant" areas north of Elba Island and in 259 the $\mathrm{CC}$, the speed is bounded by $20 \mathrm{~cm} / \mathrm{s}$. Note that high frequency motions, shown as loops 260 in the tracks, are ubiquitous in most of the drifter data. These motions have speeds of 10-20 
$261 \mathrm{~cm} / \mathrm{s}$. Spectral analysis revealed that they correspond to near-inertial oscillations, tidal

262 motions and currents driven by sea breeze. These high frequency motions are not considered

263 in the rest of the paper since the main focus is on dynamics at meso- and submesoscales.

265 Pseudo-Eulerian statistics were calculated from the drifter data for the period 3 July to 27 266 August 2010 using bins of $0.05^{\circ}$ latitude $\times 0.05^{\circ}$ longitude. The number of hourly drifter 267 observations in the bins is maximum (in excess of 500) north of Elba Island and in the 268 southern part of the CC (not shown). Mean currents are shown in Fig. 4. for bins with more 269 than 5 hourly observations. The strong anticyclonic circulation around Capraia Island is 270 striking with mean speeds reaching $30 \mathrm{~cm} / \mathrm{s}$. This feature is about $60-70 \mathrm{~km}$ in diameter and is 271 bounded by $9^{\circ} 30^{\prime} \mathrm{E}$ and $10^{\circ} 20^{\prime} \mathrm{E}$ in longitude and $42^{\circ} 50^{\prime} \mathrm{N}$ and $43^{\circ} 30^{\prime} \mathrm{N}$ in latitude. Its 272 center is just to the northeast of Capraia Island. The period of rotation is 5-10 days. In total, 273 eight drifters executed 13 loops in this structure between 19 July and 19 August (one month). 274 Two drifters executed 4 loops each.

276 Fig. 5 shows the geographical distribution of the variability of the surface currents with 277 respect to the mean pattern shown in Fig. 4. The eddy kinetic energy (see definition in 278 Poulain, 2001) is low in the eastern part of the study area and in the southern CC. It increases 279 near the northern tip of Corsica and the northern extension of the CC (in the ECC) and the 280 northern limb of the anticyclonic circulation around Capraia Island.

\subsection{Wind forcing, near-surface currents and numerical simulations}

283 The COSMO-ME wind products at the grid point nearest the CNR mooring in the CC (43

$2847.5^{\prime} \mathrm{N}, 9^{\circ} 37.5^{\prime} \mathrm{E}$, see Fig. 1) were considered to study the variability of the near-surface 285 currents related to the wind forcing. As shown in Fig. 6, in addition to daily variations 286 corresponding to sea breeze (see thin curve in middle panel), the wind is alternating between 
287 northerly and southerly regimes with a periodicity of about a week. More specifically, major 288 northerly wind events occurred on 19, 24 and 30 July and on 6 and 21 August. On 14, 22 and 28929 July and 15-16 and 27 August, winds were primarily southerly. Fig. 6 shows that the low290 pass filtered currents at $32 \mathrm{~m}$ depth measured by the mooring in the $\mathrm{CC}$ respond to the local 291 wind forcing, i.e., major events of southerly (northerly) winds correspond to increased 292 northward (southward) velocity. The correlation with zero-time lag between the meridional 293 winds and currents is about 0.69 , but it increases to 0.71 for a lag of $5 \mathrm{~h}$. This means that the 294 currents are barely delayed with respect to the wind.

296 If we plot the low-pass filtered drifter meridional velocities versus time along with the low297 pass filtered near-surface meridional flow in the Corsica Channel (Fig. 6, bottom panel), it is 298 striking that most drifter speeds co-vary with the mooring data. In particular, during the 299 events of strong northward flow (and southerly winds) of 13-14, 22-23 and 28-29 July, most 300 drifters are moving northward with speeds up to about $50 \mathrm{~cm} / \mathrm{s}$ (after low-pass filtering). On 301 18-19, 23-24 and 29-30 July under northerly wind forcing the majority of drifters are moving

302 southward and the upper current in the $\mathrm{CC}$ is reversed (southward). Note that the variance of 303 the drifter meridional velocity is much higher than the mooring data mostly due to the spatial 304 variability sampled by the drifters.

306 Fig.7 shows the average surface circulation in the Ligurian Sea in July - August 2010 307 produced by ROMS. The two-month average clearly suppresses all short-term variability and 308 the emerging picture is controlled by the permanent features in the area. The overall 309 circulation of the western Ligurian Sea is cyclonic. Surface Atlantic Water (AW) enters the 310 Ligurian Sea from the south, mostly from the Algerian basin through the Western Corsica 311 Current (WCC). As expected in summer, the ECC in the CC is weak, in good agreement with 312 the drifter data (Fig. 4). The resulting current proceeds northward as a geostrophic frontal 
313 system becoming the so-called Northern Current (NC) in the northern Ligurian Sea. In the

314 eastern Ligurian Sea, the Capraia anticyclone, identifiable in Fig. 7 by the relative maximum

315 in sea surface elevation, was a robust permanent feature of summer 2010.

317 In order to test the relationship with wind impulses, a Capraia Index was defined as the 318 difference in sea surface elevation between points A and B (see location in Fig. 7, top panel); 319 thus, a value close to zero corresponds to a wide shelf current whereas a large positive value is 320 suggestive of a strong anticyclone. The choice of an index that included point C (see Fig. 7)

321 was discarded, as the difference in sea surface elevation with respect to A may be due to a 322 structured boundary current (i.e., the WCC) disregarding the existence of the anticyclone. 323 From the time-series of the Capraia index (Fig. 7, middle panel) it can be seen that (a) the 324 anticyclone grows in intensity from early July to the end of August and (b) significant wind 325 events have the ability to partially or totally suppress the feature, with the noticeable example 326 of the (southwesterly) storm on 14-15 August (see wind speed in Fig. 7 bottom panel). As the 327 wind impulse weakens however, the index is suggestive of a re-emergence of the feature. The 328 southerly wind event around 13-14 July is in good agreement with the reversal of the coastal 329 current revealed by the drifters (Fig. 2).

\subsection{Surface circulation and satellite images}

333 During the period of glider operation (3-20 July) only 8 MODIS images were partially cloud

334 free and provided a useful description of chlorophyll concentration and the associated near335 surface circulation. On the day of the drifter and glider deployments (3 July), there was a 336 rather well-developed area of water with high chlorophyll concentration off the continental 337 Italian coast from the Arno River mouth to about $43^{\circ} \mathrm{N} 15^{\prime}$ (Fig. 8a). This increased optical 338 signal is related to the higher nutrients discharged by the river. The significant Arno plume 
339 was probably the result of an event on high discharge rate (reaching nearly $200 \mathrm{~m}^{3} / \mathrm{s}$ ) around

34021 June 2010 (data courtesy of Regione Toscana). The image confirms that the two groups of

3419 drifters were deployed in and outside the coastal layer. The next two days (4 and 5 July, Fig.

$3428 \mathrm{~b}, \mathrm{c})$, while all drifters were moving southward, the coastal layer developed two instabilities

343 forming offshore-flowing (and also southward flowing) filaments near $43^{\circ} 25^{\prime} \mathrm{N}$ and $43^{\circ} 10^{\prime}$

344 N. On 8 July (Fig. 8d), these instabilities were well separated in latitude and showed cyclonic

345 veering, that is offshore and southward circulation. The rich water of the southern instability

346 was advected towards Elba Island and then westward towards Corsica. There is a particularly

347 good agreement between the chlorophyll structures and the drifter tracks.

349 The offshore-flowing instabilities rooted on the Italian continental coast were still present 350 between 10 and 19 July (Fig. 9) with various shapes and offshore extensions. The northern 351 one extended as far as the Gorgona Island. Others developed near and south of Elba Island, 352 but were away from the areas sampled by the drifters and glider. To the west, off Corsica, an 353 instability plume was evident on 12, 17 and 19 July (Fig. 9b,c,d). On 12 July (Fig. 9b) drifters 354 were even trapped in it as it developed more offshore (as far as east as $9^{\circ} 45^{\prime} \mathrm{E}$ ).

356 During its entire mission, the glider protruded in and out of the chlorophyll-rich waters. For 357 instance, on 8 July (Fig. 8d) it encountered richer waters near the surface at both extremities 358 of this southwestward transect.

3.4 Water mass properties and geostrophic currents in the water column

362 The distribution of temperature, salinity and density along the glider track is discussed here 363 below, with main focus on the top $40 \mathrm{~m}$ of water where most of the variability occurs. 364 Selected transect (1, 8 and 15, see location in Fig. 1) are considered for the sake of brevity. 
366 During its entire operation, the glider revealed a near-surface mixed layer extending down to

367 5-10 m (Figs. 10-12) on top of a thermocline spreading between approximately 10 and $40 \mathrm{~m}$.

368 Along the northernmost transect 1 (Fig. 10) the isotherms and isopycnals are inclined

369 (deepening going offshore to the $\mathrm{W}$ ) and the corresponding geostrophic currents are directed

370 southward. Further to the south, along transect 8 (Fig. 11), the above-mentioned iso-curves

371 are characterized by a concave upward structure. Qualitatively, the geostrophic currents are to

372 the SW in the eastern portion, where the drifters also move to the S and SW (see Fig. 8d).

373 More offshore (to the W) the currents are reversed, thus representing a mesoscale anticyclonic

374 circulation feature. In the southern part of the $\mathrm{CC}$, along the zonal transect 15 (Fig. 12), the

375 isotherms and isopycnals correspond to concave downward. Again this is compatible with the 376 southward motion of the drifters near Corsica, and the usual northward direction of the ECC,

377 which is rather weak in summer.

379 Low-salinity water of Arno River origin (as demonstrated before in satellite images) extends 380 almost across the entire section but most importantly for distances larger than $2 \mathrm{~km}$ from the 381 westernmost point (Fig. 10). Water with salinity less than 37.6 prevails in the top 5-m layer.

382 Below it, the salinity is gradually increasing and reaching values in excess of 38.0 around 40

$383 \mathrm{~m}$ depth. This is a signature of the upper core of the Levantine Intermediate Water which can 384 reach salinity of 38.6-38.7 at depths of 300-500 $\mathrm{m}$ in the Ligurian Sea (Bosse et al., 2015).

385 Besides the above-described features, the high horizontal resolution of the glider allowed to 386 sample a vein of relatively low salinity ( 37.6) expanding offshore along transect 1 (Fig. 10) 387 between 10 and $25 \mathrm{~m}$ depth. The inclination of the vein is compatible with the slope of the 388 isopycnals and indicates the subduction of coastal water. 
390 Along transect 8 the near surface salinity above $10 \mathrm{~m}$ has two minima (near 37.0 ) at the 391 extremities, corresponding to the Arno River plume extending offshore (to the east), and

392 presumably to the Atlantic Water coming from the CC (to the west). This low-salinity water

393 is also seen in transect 15 across the CC, although a little bit deeper $(5-10 \mathrm{~m})$ and capped 394 partially by saltier water.

396 In the CC (eastern part of transect 15), the glider data show consistent northward currents in 397 the entire depth range $(0-200 \mathrm{~m})$ whereas the mooring currents (Fig. 13) show mostly 398 northward currents above $80 \mathrm{~m}$, with intensification on 13-14, 22 and 29 July and 14-15 399 August. Below, there are 1-2 weeks long periods of flow reversal, the most prominent one 400 lasting from 14 to 25 July and involving the water column up to $60 \mathrm{~m}$ depth. The surface 401 northward velocities average was $11.2 \pm 7.4 \mathrm{~cm} / \mathrm{s}$, while the southward ones were much weaker $402 \quad(-2.8 \pm 2.6 \mathrm{~cm} / \mathrm{s})$.

\section{Discussion and conclusions}

407 During summer 2010, surface drifters and a glider were operated simultaneously to explore 408 the dynamics of the southeastern Ligurian Sea where the wind forcing, the local 409 geography/bathymetry and the outflow of the Arno River are supposed to affect significantly 410 the circulation and the distribution of the water mass properties. The glider was piloted in 411 order to obtain information in the water column in the area sampled by most of the drifters.

412 Ancillary data were obtained from a permanent mooring in the $\mathrm{CC}$ and from satellites 413 (MODIS images of chlorophyll concentration). In addition, a ROMS numerical model was 414 used to simulate the local dynamics and to help with the interpretation of the collected data. 
416 The drifters revealed a surface circulation strongly affected by the local winds. Southward

417 currents dominated off the Italian continental coast. These currents reversed on 13-14 July due

418 to a change in wind direction, changing to southerly. The fluctuation of surface currents

419 between the southward and northward directions is seen in the drifter tracks over the entire

420 study area (in particular in the vicinity of Capraia Island) and in the near-surface records of 421 the mooring in the CC (see Fig. 6) during July and August 2010. The typical period of these 422 oscillations is one week.

424 Some drifters eventually depicted a strong anticyclonic circulation pattern centered on 425 Capraia Island (the Capraia anticyclone) starting on 20 July. The rotation period of these 426 drifters is 5-10 days, that is, slightly longer than the value (3 days) reported by Poulain et al. 427 (2012). Both drifters (Fig. 2) and the simulated sea surface height (Capraia index in Fig. 7) 428 showed an enhancement of the Capraia anticyclone in late July and August, only interrupted 429 by a storm on 14-15 August. This trend is related to the increase of negative vorticity of the 430 winds from July to August (not shown). On 14-15 August, strong winds from the SW 431 disrupted this trend and the anticyclone essentially vanished. In conclusion, ROMS numerical 432 model successfully simulated the occurrence of the Capraia anticyclone as a semi-permanent 433 and strengthening feature during July-August 2010, corroborating the hypothesis of the 434 significant role played by wind-storms in perturbing this eddy as well as the surface 435 circulation in the area.

437 The southward coastal currents advected the plume of the Arno River and associated 438 filaments of nutrient-rich waters towards the south, forming a layer of high chlorophyll 439 concentration along most of the Italian continental coast. This layer became unstable and 440 offshore-flowing filaments were generated typically at two locations between the Arno mouth 441 and Elba Island (see for instance Fig. 8d.). The northernmost filament reached almost the area 
442 near Gorgona Island (Fig. 9d) and the southern one was advected near the northern coast of

443 Elba Island, into the CC and around Capraia Island (Fig. 8c,d).

444

445 The temperature, salinity and density data provided by the glider between 3 and 20 July 2010

446 show stratified conditions typical of summer with a surface mixed layer down to $10-20 \mathrm{~m}$, a

447 thermocline expanding down to a maximum depth of $40 \mathrm{~m}$. In terms of salinity, horizontal 448 variability (fronts) associated with the Arno plume and/or the AW occur along most transects.

449 For the Arno plume and its extension into offshore-flowing filaments, there is a good 450 agreement between the satellite chlorophyll images and the glider data. In the thermocline, an

451 inclined intrusion of fresher water (probably of Argo River origin) observed in transect 1 (Fig. 452 10) corresponds to subduction along isopycnals. Below $40 \mathrm{~m}$, the increase of salinity with 453 depth represents the upper part of the LIW.

455 Currents measured at the CNR mooring in the CC corroborated the fluctuations of the near456 surface circulations with events of northward flow on 13-14, 22 and 29 July and 14-15 August 457 also experienced by the drifters (Fig. 13). Deeper in the water column, southward reversing 458 flow was observed for longer period (1-2 weeks) and rather independently from the surface 459 variability. These flow reversal events have already been reported by Astraldi et al. (1990). 460 They are not forced by the local winds but are probably related to the sea level difference 461 between the Tyrrhenian and Ligurian Sea.

463 The combined use of data provided by mobile and fixed autonomous instruments (drifters, 464 glider, mooring), by environmental satellites and numerical simulations in the southeastern 465 Ligurian Sea exemplifies an efficient way of collecting oceanographic data in this complex 466 sea area at relatively low costs. Obviously, a better sampling approach could have involved 467 data collection with more than one glider, the deployment of fixed moorings at key locations, 
468 and an extensive survey of the entire study area with a research vessel. The study of coastal

469 dynamics as described in this paper, nevertheless, is a good example of multi-platform and

470 multi-parameter approach, which is the future paradigm in observational oceanography.

\section{Acknowledgements}

473

474 The authors are grateful to all the people who helped with the drifter and glider 475 deployment/recovery operations and with the data processing, and in particular to P. Zanasca, 476 A. Bussani, M. Menna, I. Mancero-Mosquera and K. Mahiouz. The drifters used in LIDEX10 477 were kindly provided by the NATO NURC Center (La Spezia, Italy), CNR, University 478 Parthenope of Naples and OGS. The glider (TENUSE) was contributed by LOCEAN. The 479 satellite data were downloaded from https://modis.gsfc.nasa.gov/data/dataprod/ . ODAS wind 480 data were provided by the EU FP7 EuroSITES project. COSMO-ME data were kindly made 481 available by CNMCA in Rome, Italy. Arno River data are courtesy of Servizio Idrologico 482 Regione Toscana. E. Z and P. F acknowledge support from the Parthenope University 483 individual and group research funding. 


\section{References}

Alvarez, A., Chiggiato, J., Mourre, B., 2012. Robotic characterization of access-restricted

490 marine environments. IEEE Rob. Autom. Mag., 20 (3), 42-49.

491

492 Astraldi, M., Gasparini, G.P., Manzella, G.M.R., Hopkins, T.S., 1990. Temporal variability of 493 currents in the eastern Ligurian Sea, J. Geophys. Res., 95(C2), 1515-1522.

495 Astraldi, M., Gasparini, G.P., 1992. The seasonal characteristics of the circulation in the

496 North Mediterranean basin and their relationship with the atmospheric climatic conditions. J.

497 Geophys. Res., 97 (C6), 9531-9540.

499 Bosse, A., Testor, P., Mortier, L., Prieur, L., Taillandier, V., d’Ortenzio, F., Coppola, L., 500 2015. Spreading of Levantine Intermediate Waters by submesoscale coherent vortices in the 501 northwestern Mediterranean Sea as observed with gliders, J. Geophys. Res. Oceans, 120, 502 1599-1622, doi:10.1002/ 2014JC010263.

504 Bouffard, J., Vignudelli, S., Cipollini, P., Menard, Y., 2008. Exploiting the potential of an 505 improved multimission altimetric data set over the coastal ocean, Geophys. Res. Lett., 35, 506 L10601, doi: 10.1029/2008GL033488.

508 Ciuffardi, T., Napolitano, E., Iacono, R., Reseghetti, F., Raiteri, G., Bordone, A., 2016.

509 Analysis of surface circulation structures along a frequently repeated XBT transect crossing 510 the Ligurian and Tyrrhenian Seas. Ocean Dynam., 66(6-7), 767-83. 
512 Haidvogel, D.B., Arango, H., Budgell, W.P., Cornuelle, B.D., Curchitser, E., Di Lorenzo, E.,

513 Fennel, K., Geyer, W.R., Hermann, A.J., Lanerolle, L., Levin, J., McWilliams, J.C., Miller,

514 A.J., Moore, A.M., Powell, T.M., Shchepetkin, A.F., Sherwood, C.R., Signell, R.P., Warner,

515 J.C., Wilkin, J., 2008. Ocean forecasting in terrain-following coordinates: Formulation and

516 skill assessment of the Regional Ocean Modeling System. J. Comput. Phys., 227: 3595-3624.

518 Manzella, G., 1985. Fluxes across the Corsica Channel and coastal circulation in the East

519 Ligurina Sea. Morth-Western Mediterranean, Ocean. Acta, 8 (1), 29-35.

521 Marchesiello, P., McWilliams, J. C., Shchepetkin, A. F., 2001. Open boundary conditions for 522 long-term integration of regional oceanic models. Ocean Modell., 3, 1-20.

524 Menna, M., Gerin R., Bussani A., Poulain P.-M., 2017. The OGS Mediterranean Drifter 525 Dataset: 1986-2016. Rel. OGS 2017/92 Sez. OCE 28 MAOS, OGS, Trieste, Italy.

527 Mourre, B., Chiggiato, J., 2014. A comparison of the performance of the 3-D super-ensemble 528 and an ensemble Kalman filter for short-range regional ocean prediction. Tellus A, 66, 21640.

530 Mourre, B., Chiggiato, J., Lenartz, F., Rixen, M., 2012. Uncertainty forecast from 3-D super531 ensemble multi-model combination: Validation and calibration. Ocean Dynam., 62(2): 283532294.

534 Oddo, P., Adani, M., Pinardi, N., Fratianni, C., Tonani, M., and Pettenuzzo, D., 2009. A 535 nested Atlantic-Mediterranean Sea general circulation model for operational forecasting, 536 Ocean Sci., 5, 461-473, doi:10.5194/os-5-461-2009. 
538 Onken, R., Robinson, A.R., Kantha, L., Lozano, C.J., Haley, P.J., Carniel S. 2005. A rapid 539 response nowcast/forecast system using multiply-nested Ocean models and distributed data 540 systems, J. Mar. Sys., 56, 45-66.

542 Pinardi, N., Masetti, E. 2000. Variability of the large-scale general circulation of the 543 Mediterranean Sea from observations and modelling: a review. Palaeogeography, 544 Palaeoclimatology, Palaeoecology, 158, 153-173.

546 Pinardi, N., Arneri E., Crise A., Ravaioli M., Zavatarelli M. 2006. The physical, sedimentary 547 and ecological structure and variability of shelf areas in the Mediterranean Sea. In: A. R. 548 Robinson and K. Brink (eds.), The Sea, Vol. 14 Harvard University Press, Cambridge, USA, $549 \quad 1245-1330$.

551 Poulain, P.-M. 1999. Drifter observations of surface circulation in the Adriatic Sea between 552 December 1994 and March 1996, J. Mar. Syst., 20, 231-253.

554 Poulain, P.-M. (2001), Adriatic Sea surface circulation as derived from drifter data between 5551990 and 1999, J. Marine Sys., 29, 3-32.

557 Poulain P.-M., Gerin R., Rixen M., Zanasca P., Teixeira J., Griffa A., Molcard A., De Marte, 558 M., Pinardi N. 2012. Aspects of the surface circulation in the Liguro-Provençal basin and 559 Gulf of Lion as observed by satellite-tracked drifters (2007-2009), Boll. Geofis. Teor. Appli., $560 \quad 53(2), 261-279$.

562 Poulain, P.-M. Gerin, R. 2019. Assessment of the water-following capabilities of CODE 563 drifters based on direct relative flow measurements. J. Atmos. Ocean Tech., 36(4), 621-633, 564 doi: 10.1175/JTECH-D-18-0097.1 
566 Vignudelli, S., Gasparini, G.P., Astraldi, M., Schiano, M.E. 1999. A possible influence of the

567 North Atlantic Oscillation on the circulation of the Western Mediterranean Sea, Geophys.

568 Res. Lett., 26 (5), 623-626.

569

570 Vignudelli, S., Cipollini, P., Astraldi, M., Gasparini G.P., Manzella, G., 2000. Integrated use 571 of altimeter and in situ data for understanding the water exchanges between the Tyrrhenian 572 and Ligurian Seas. J. Geophys. Res., 105 (C8), 19649-19663.

573

574 Shchepetkin, A.F., McWilliams, J.C., 2005. The regional ocean modelling system: a split575 explicit, free-surface, topography-following-coordinates ocean model. Ocean Modell. 9, 347576404.

577

578 Vignudelli, S., Cipollini, P., Roblou, L., Lyard, F., Gasparini, G.P., Manzella G., Astraldi, M. 579 2005. Improved satellite altimetry in coastal systems: Case study of the Corsica Channel 580 (Mediterranean Sea), Geophys. Res. Lett., 32, L07608, doi:10.1029/2005GL022602.

582 Schroeder, K., Chiggiato, J., Haza, A.C., Griffa, A., Özgökmen, T.M., Zanasca, P., Molcard, 583 A., Borghini, M., Poulain, P.-M., Gerin, R., Zambianchi, E., Falco, P., Trees, C. 2012.

584 Targeted Lagrangian sampling of submesoscale dispersion at a coastal frontal zone. Geophys. 585 Res. $\quad$ Lett., $\quad 39, \quad$ L11608, doi:10.1029/2012GL051879. 


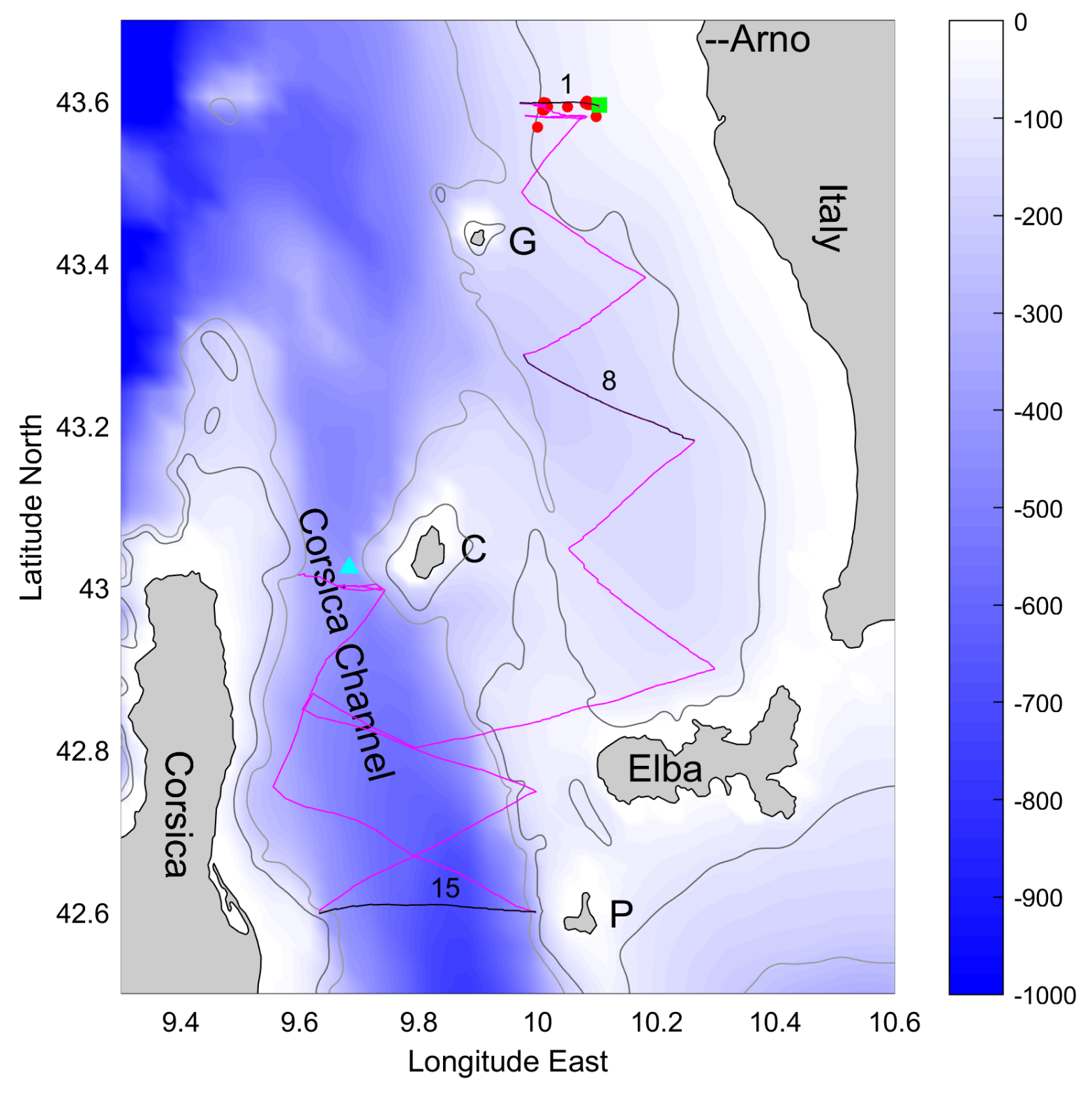

587 Figure 1. Geography and bathymetry of the study area in the southeastern Ligurian and

588 Corsica Channel. The Gorgona (G), Capraia (C) and Pianosa (P) islands are shown in addition 589 to the Elba Island. The location of the CNR mooring is shown with a cyan triangle. The 590 deployment locations of the drifters (red dots) and glider (green square) are also indicated. 591 The glider track is shown in magenta, including the 3 transects $(1,8$ and 15) described in the paper. Bathymetry is contoured (100 and $200 \mathrm{~m}$ ) and shown with blue shades (m). 

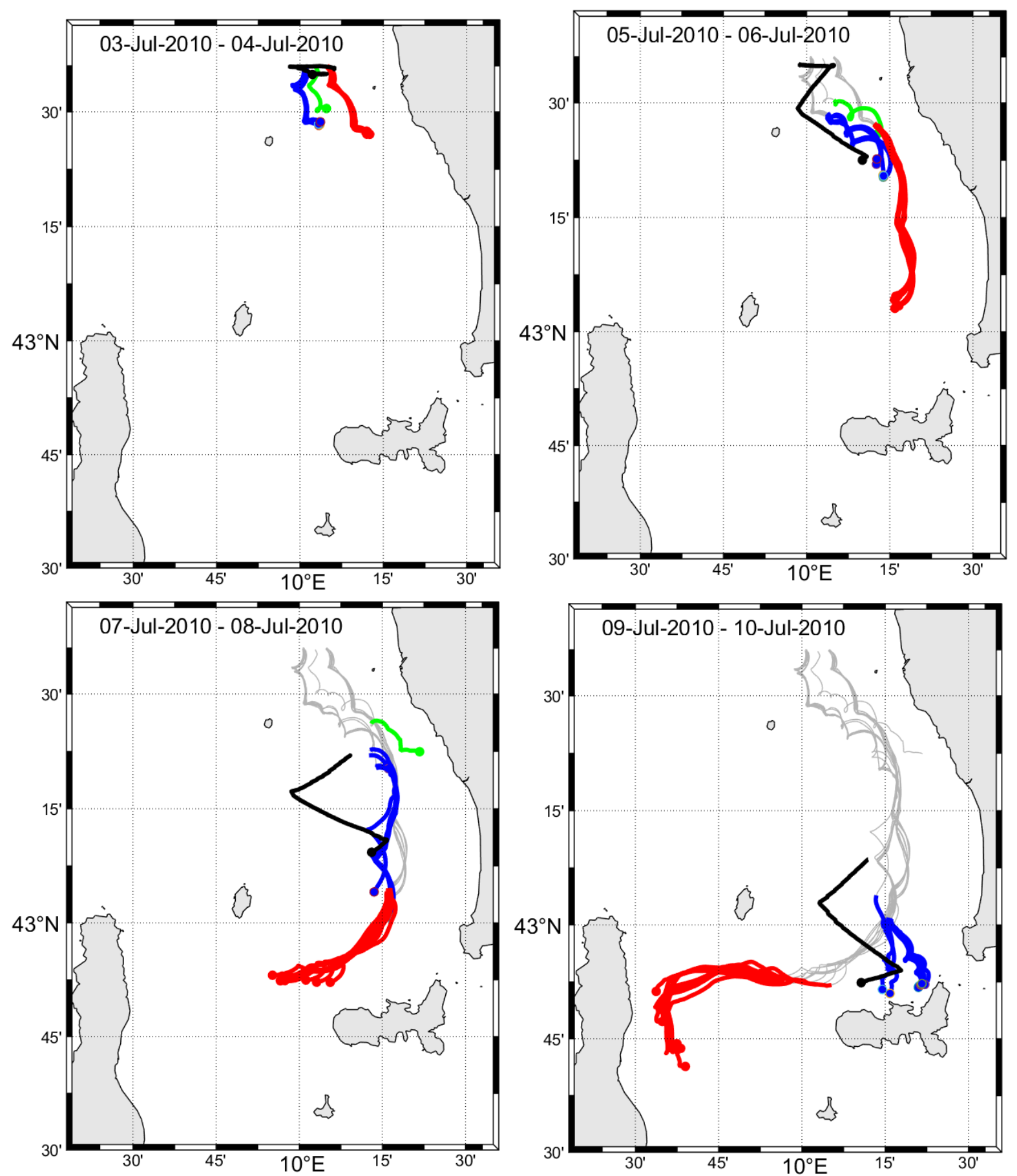

596 Figure 2. Two-day long drifter (red: coastal group; blue: outer group; green: intermediate drifter) and glider (black) track segments, with dot corresponding to the end of the second day, between 3 and 20 July. Cumulative tracks are shown in light grey shade. 

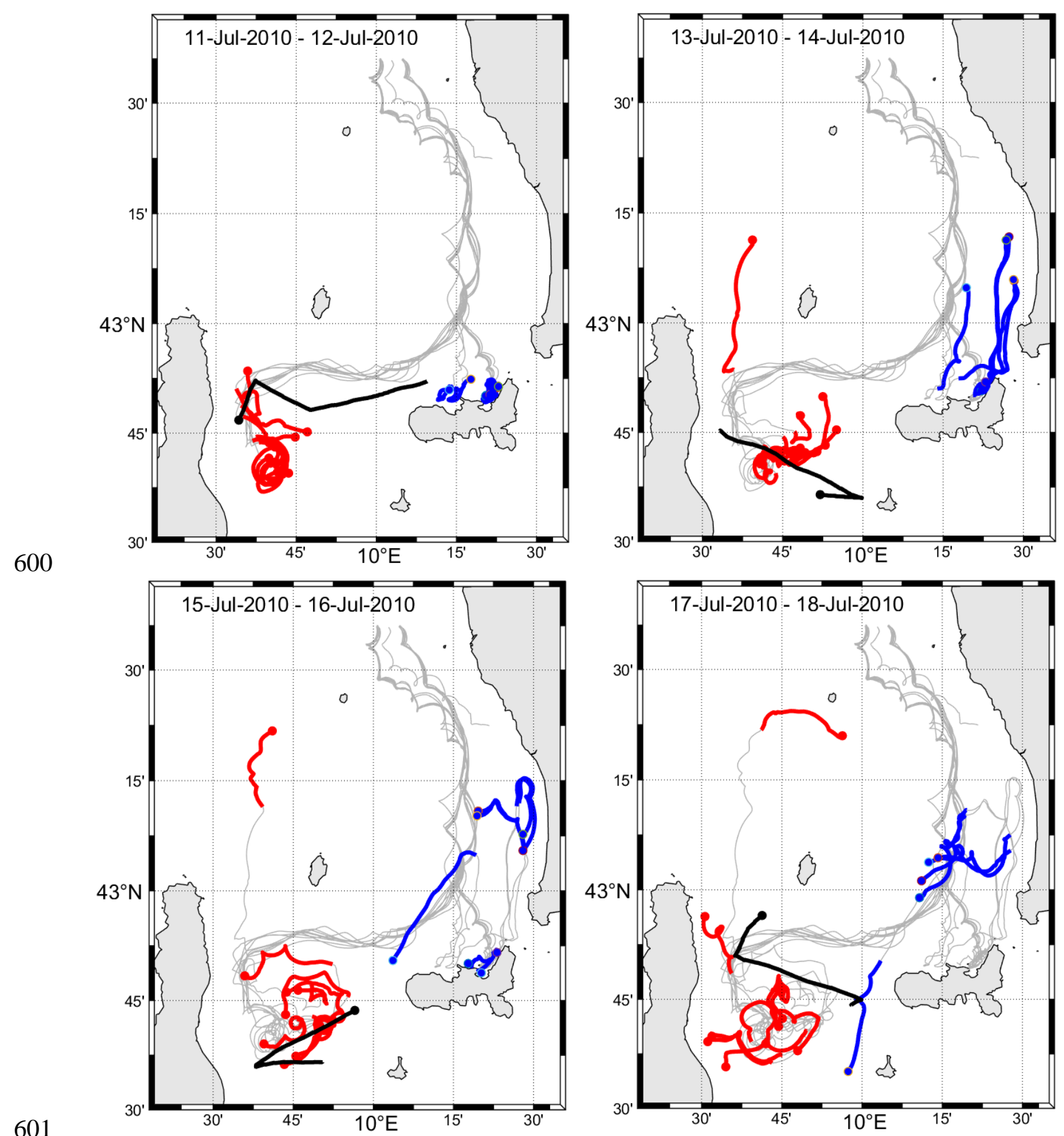

602

603

Figure 2. Continued.

604 


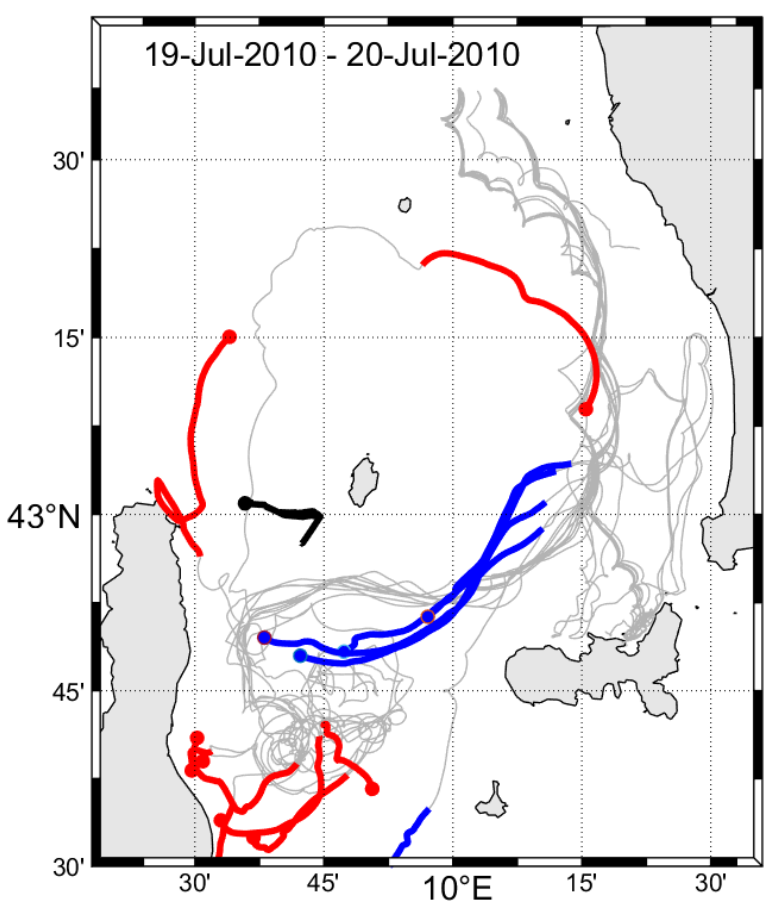

607

Figure 2. Continued.

608

609 


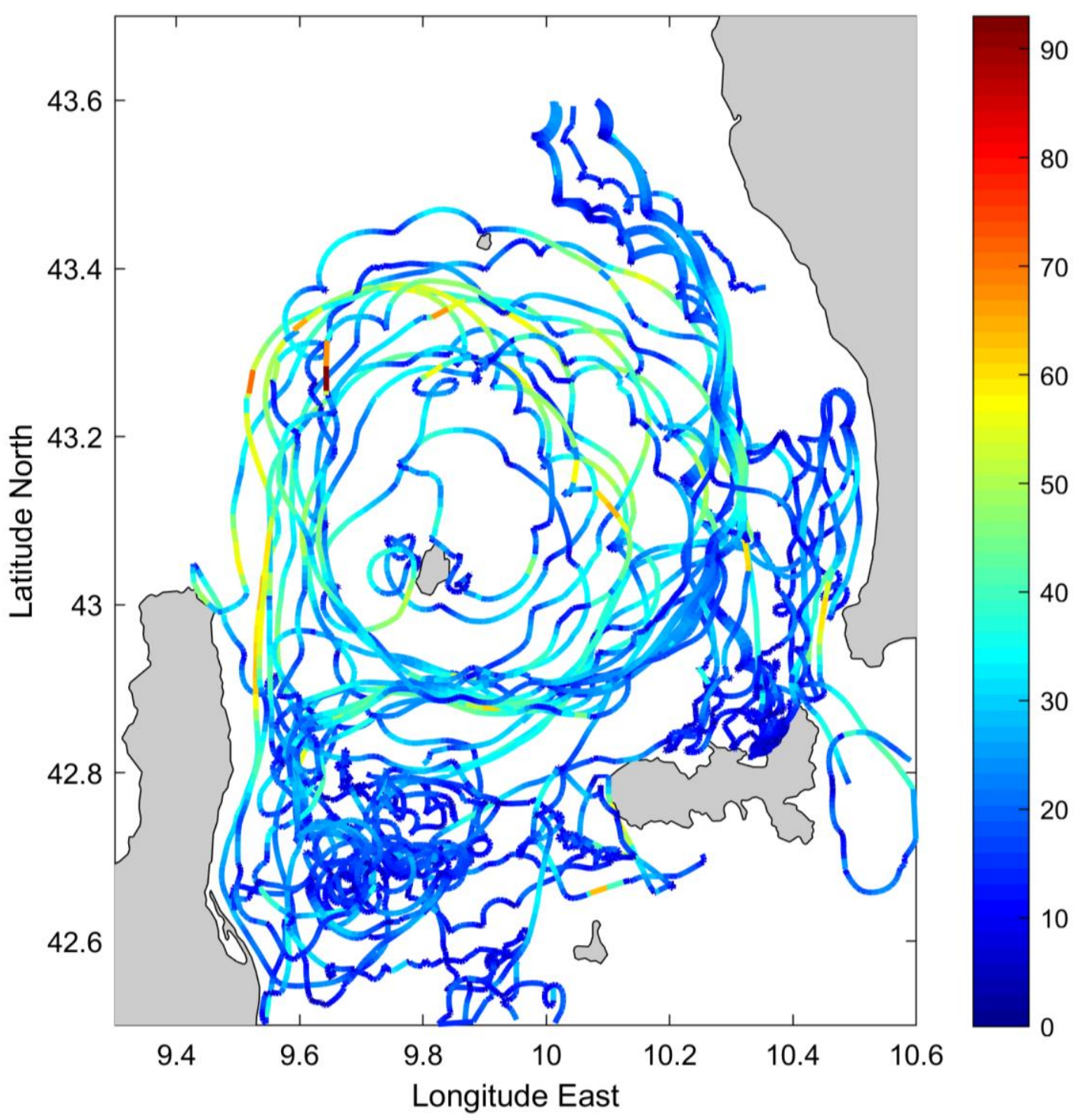

611

612 Figure 3. Drifter trajectories for the period 3 July - 27 August 2010 color-coded as a function of drifter speed $(\mathrm{cm} / \mathrm{s})$.

614

615

616

617

618

619 


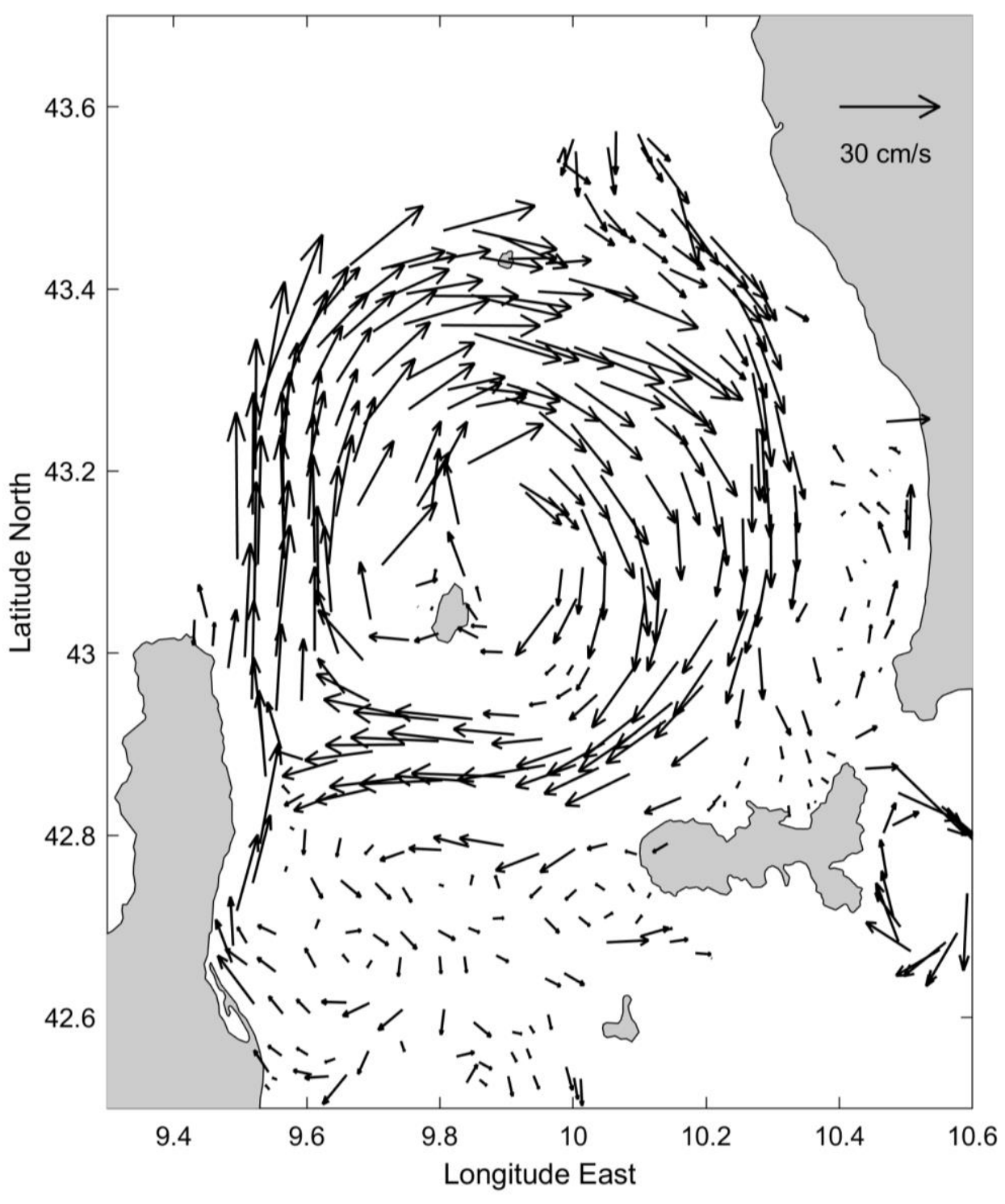

623 Figure 4. Mean surface circulation (arrows) and mean kinetic energy (colors, $\mathrm{cm}^{2} / \mathrm{s}^{2}$ ) in study 624 area for the period 3 July -27 August 2010 using bins of $0.05^{\circ} \times 0.05^{\circ}$. Bins with less than 5 hourly observations were omitted. 


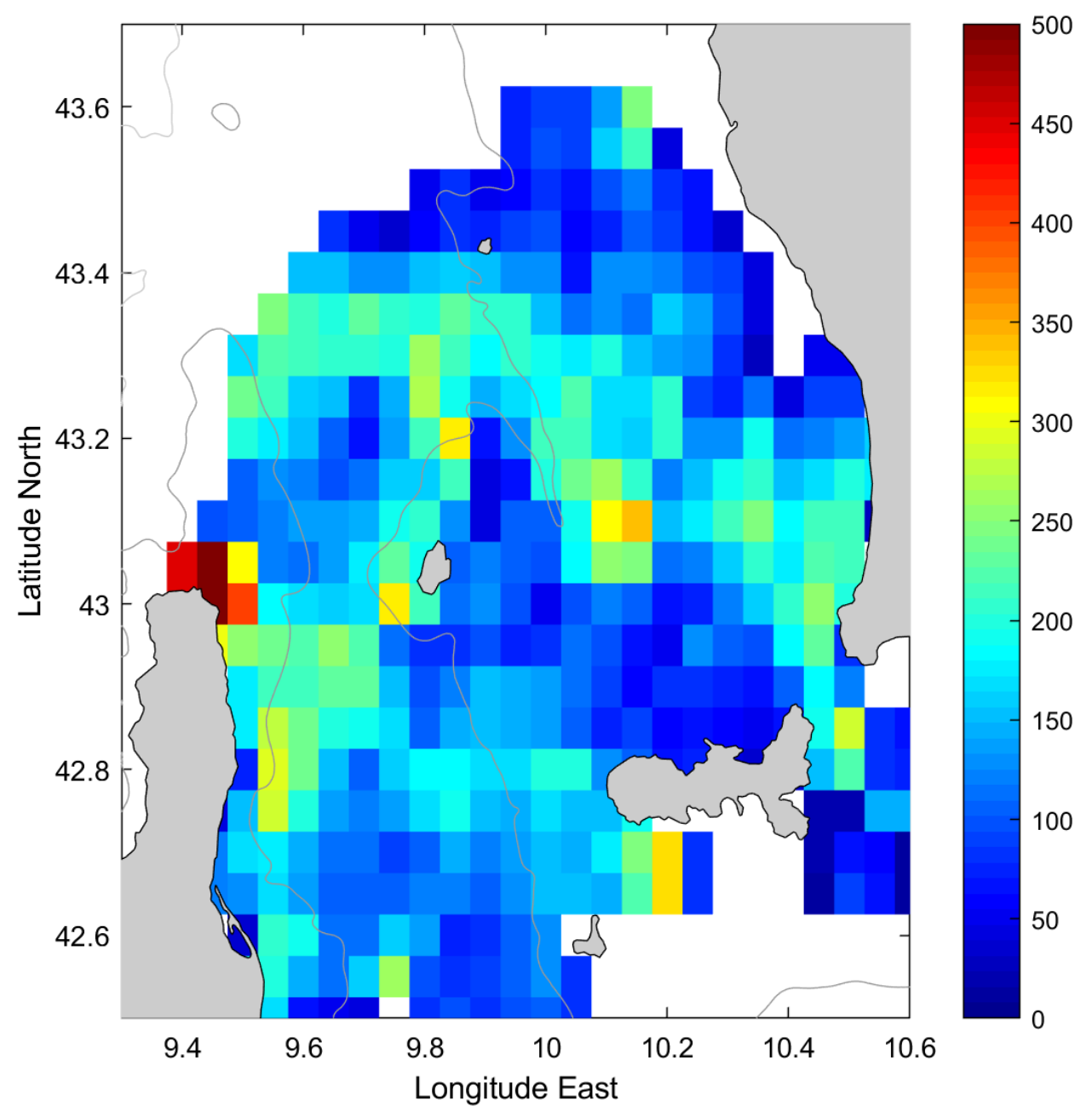

630 Figure 5. Kinetic energy per unit mass of the velocity residuals or eddy kinetic energy (EKE,

$631 \mathrm{~cm}^{2} \mathrm{~s}^{-2}$ ) in study area for the period 3 July -27 August 2010 using bins of $0.05^{\circ} \mathrm{x} 0.05^{\circ}$. Bins with less than 5 hourly observations were omitted.

633

634

635 

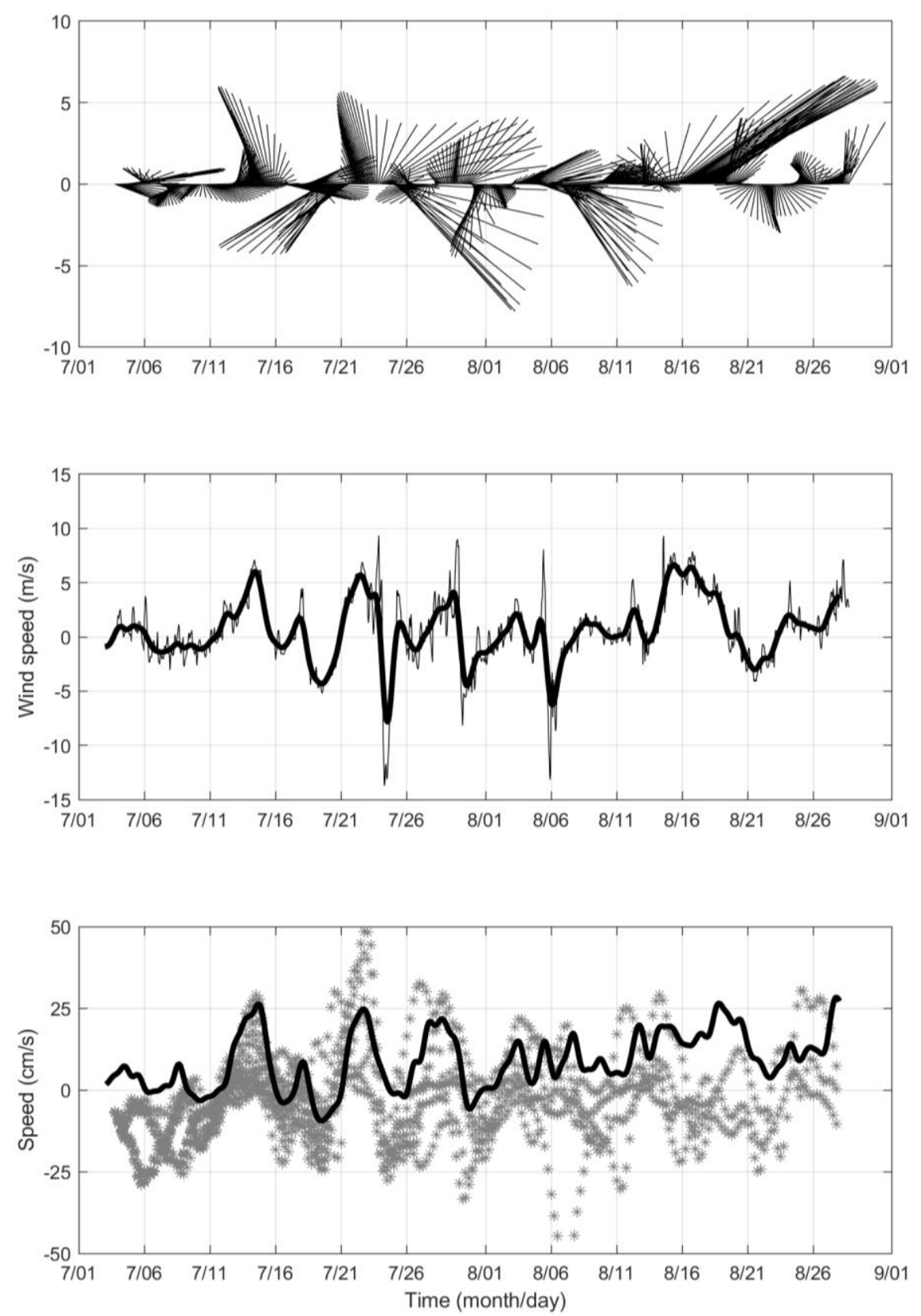

637 Figure 6. Stick diagram of the low-pass filtered COSMO-ME 10-m winds at grid point $43^{\circ}$

$6387.5^{\prime} \mathrm{N}, 9^{\circ} 37.5^{\prime} \mathrm{E}$ in the $\mathrm{CC}$ between 3 July and 27 August 2010 (top panel). Full (thin curve)

639 and low-pass filtered (tick curve) COSMO-ME 10-m wind meridional component at the same

640 location (middle panel). Low-pass filtered near-surface velocities at $32 \mathrm{~m}$ in the $\mathrm{CC}$ from

641 mooring data (thick curve) and low-pass filtered velocities (light grey stars) of all the drifters in the study area (bottom panel). 

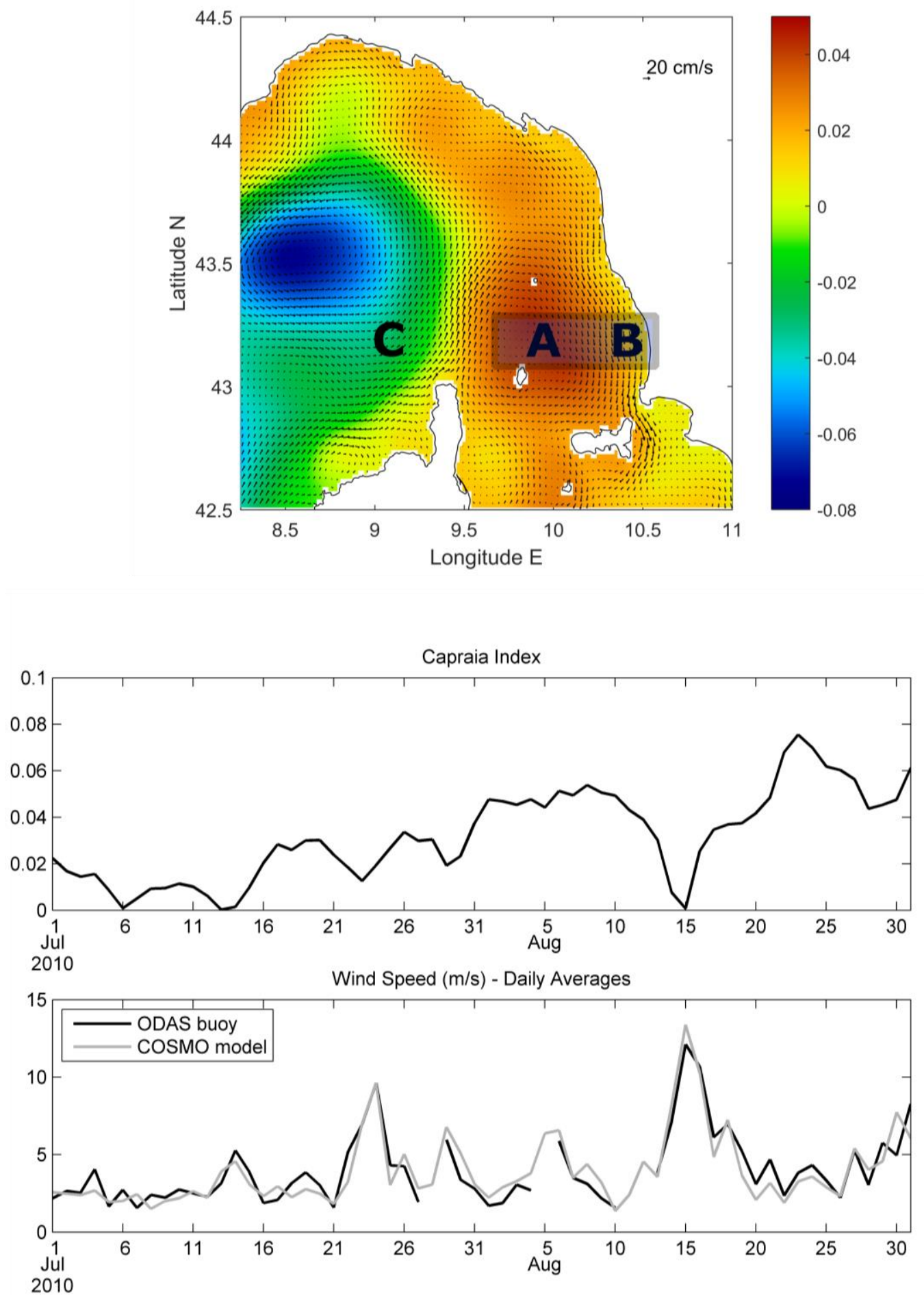

645 Figure 7. Ligurian Sea average circulation in July-August 2010 as simulated by ROMS (top

646 panel). Colour is sea surface height (m) and arrows surface currents. Evolution of the daily

647 average of the Capraia Index ( $\mathrm{m}$; middle panel) confronted to the daily average of COSMO-

648 ME 10-m wind speed (m/s) at the ODAS buoy location and the measured ODAS 10-m wind speed (bottom panel). 

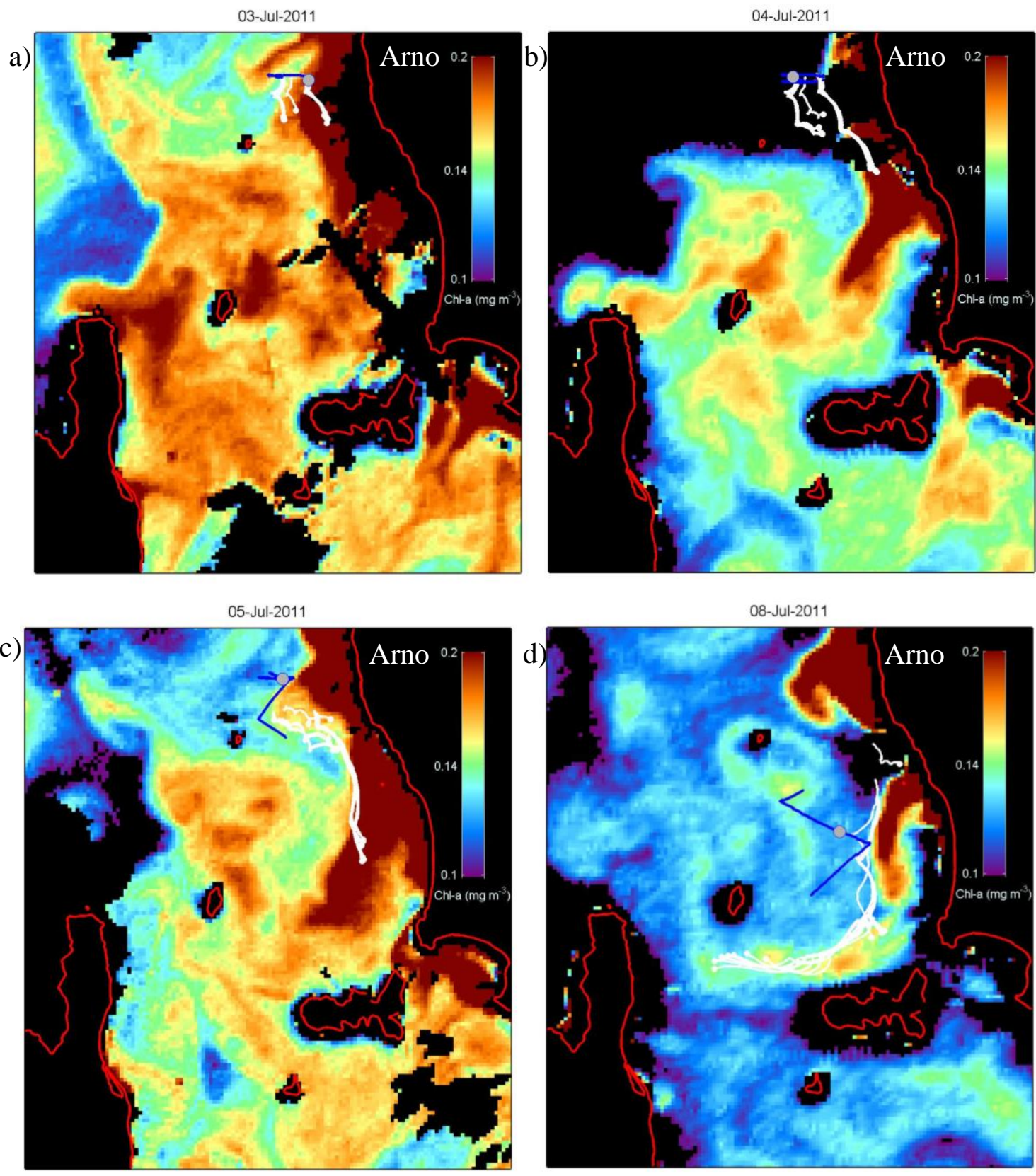

Figure 8. MODIS images of chlorophyll concentration on 3, 4, 5 and 8 July 2010,

654 superimposed with centered 2-day long trajectories of drifters (white) and glider (blue). The

655 gray dot represents the location of the glider at 12 GMT, contemporaneous with the satellite 656 images. 
10-Jul-2011

a)

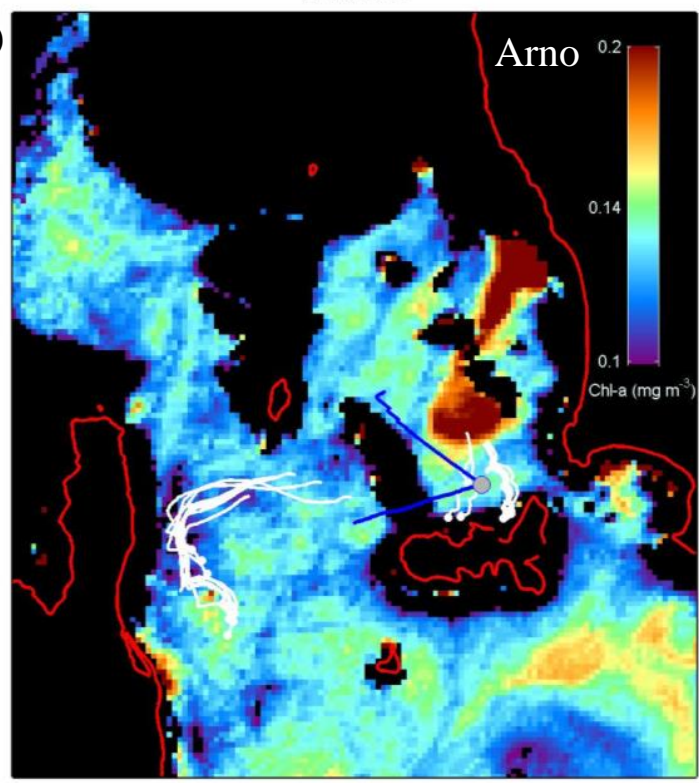

658

659

c)

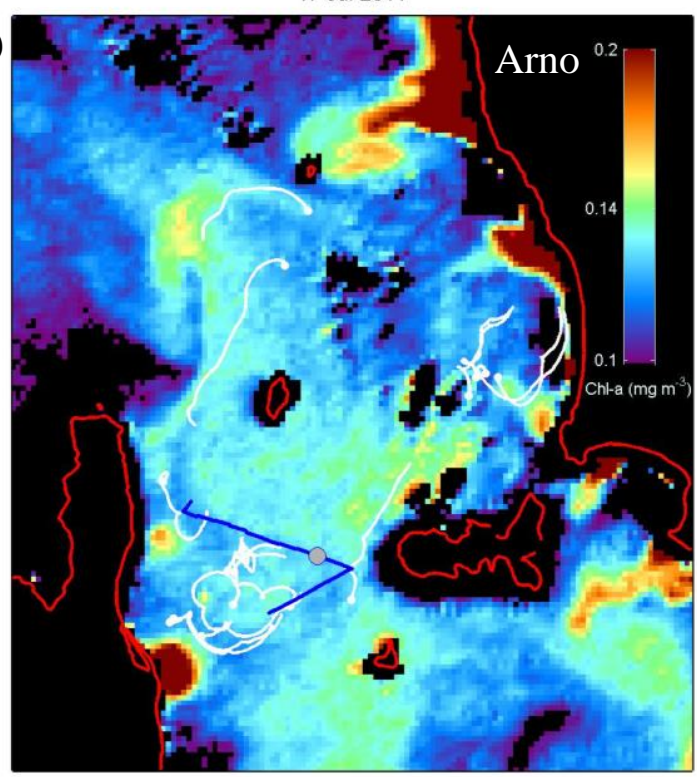

12-Jul-2011

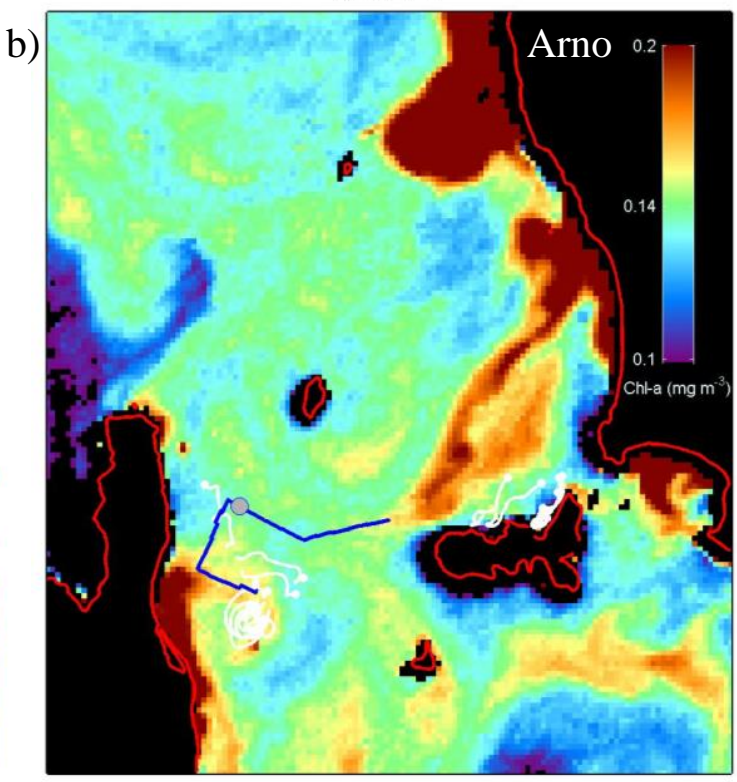

19-Jul-2011

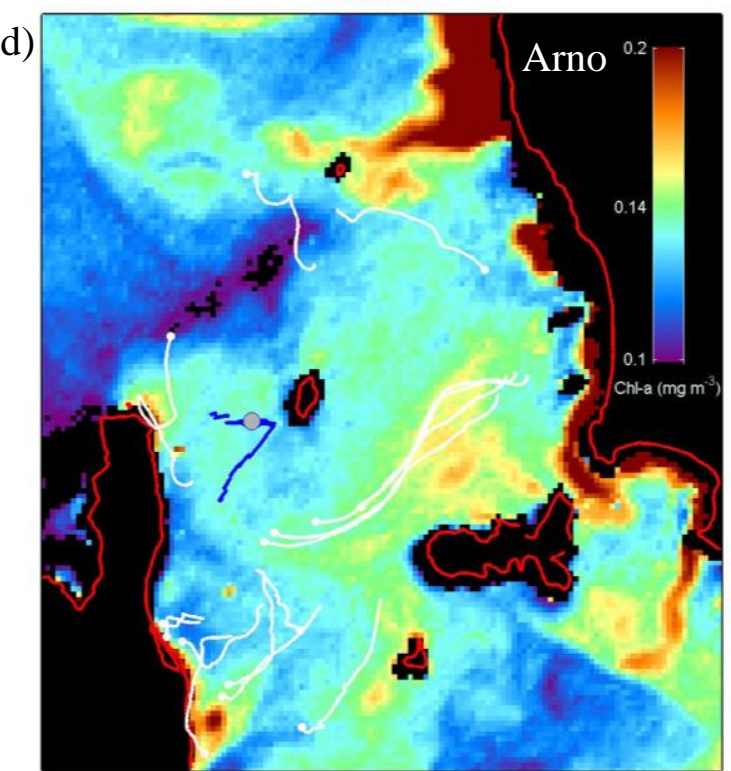

660

661

Figure 9. Same as Figure 8 but for 10, 12, 17 and 19 July 2010.

662 


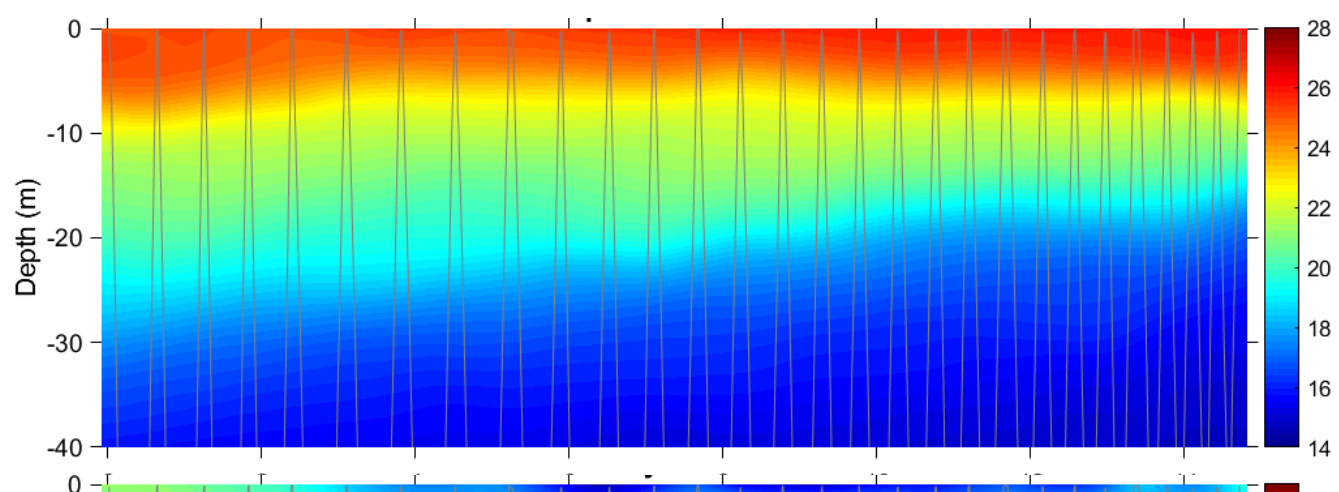

664

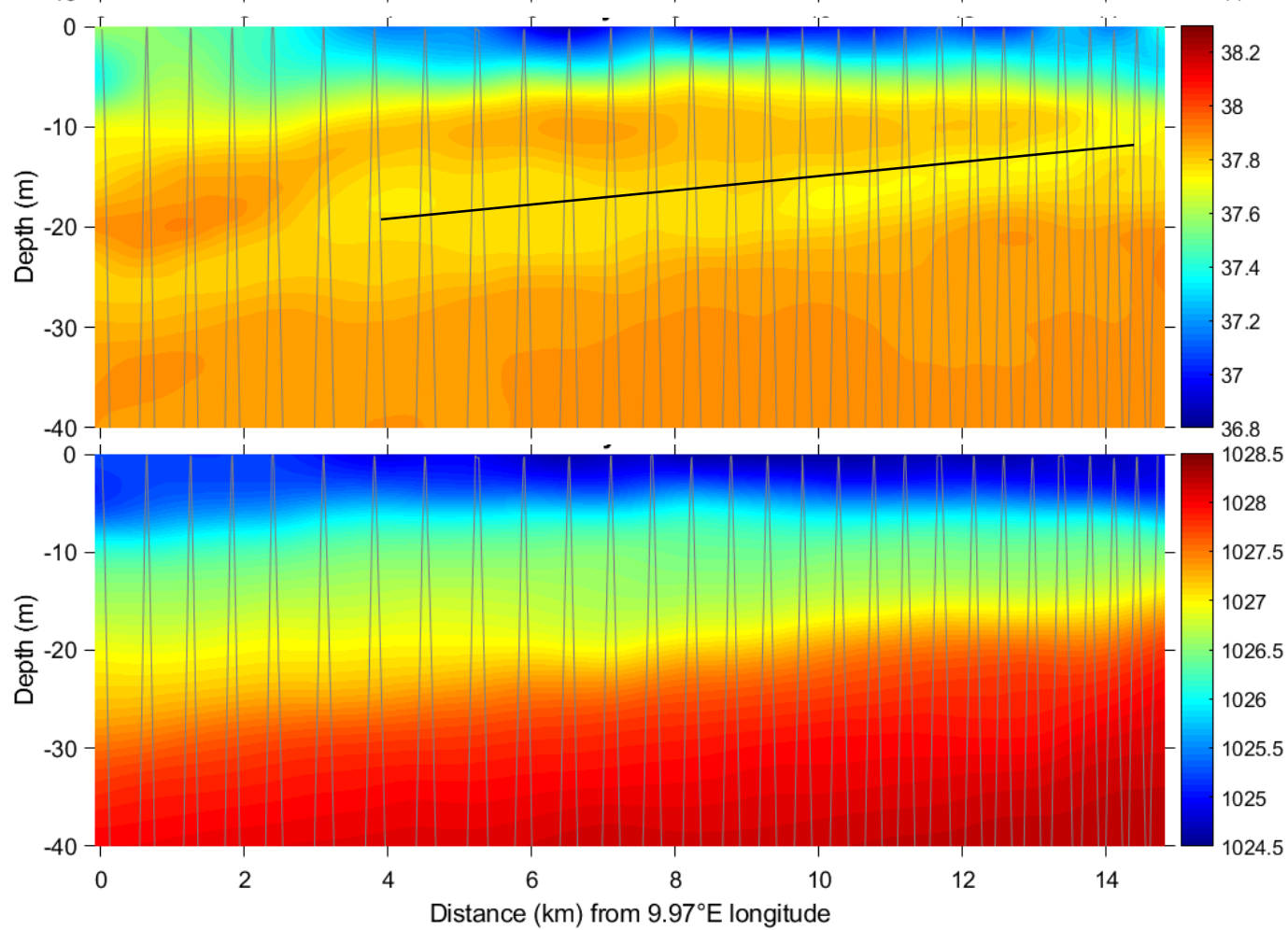

667 Figure 10. Contour plots of temperature $\left({ }^{\circ} \mathrm{C}\right.$, top), salinity (middle) and density $\left(\mathrm{kg} / \mathrm{m}^{3}\right.$,

668 bottom) versus depth and horizontal distance along glider transect 1 . The origin is the

669 westernmost location and the glider yo-yo track is shown with light grey lines. In the middle panel, a black line indicate subduction of less saline water along the isopycnals. 

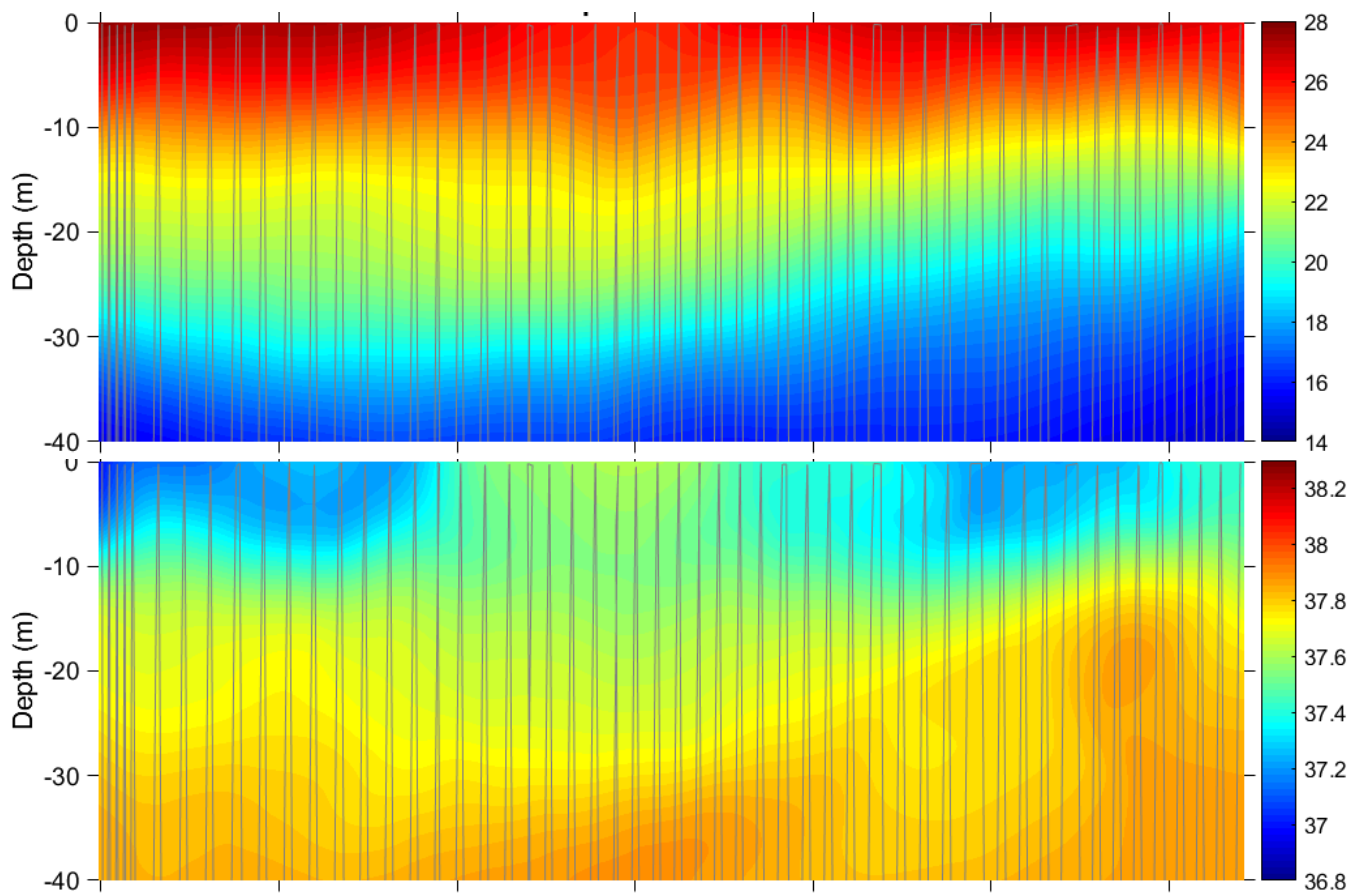

672

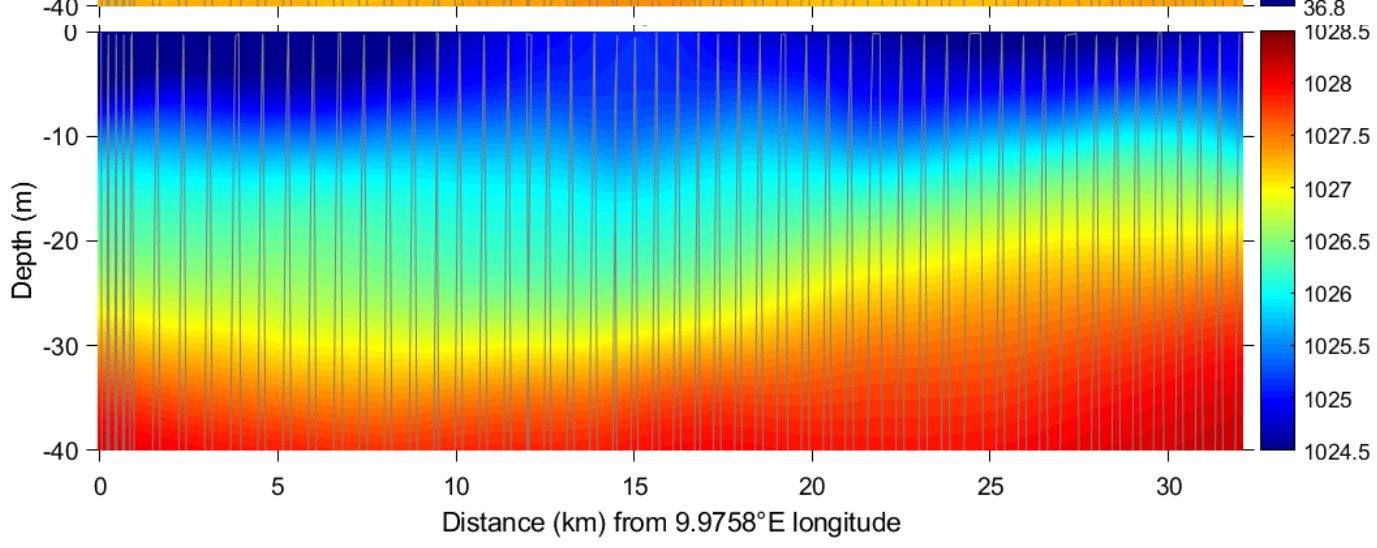

673
674

675

Figure 11. Same as in Figure 10 but for glider transect 8.

676

677

678

679

680

681 

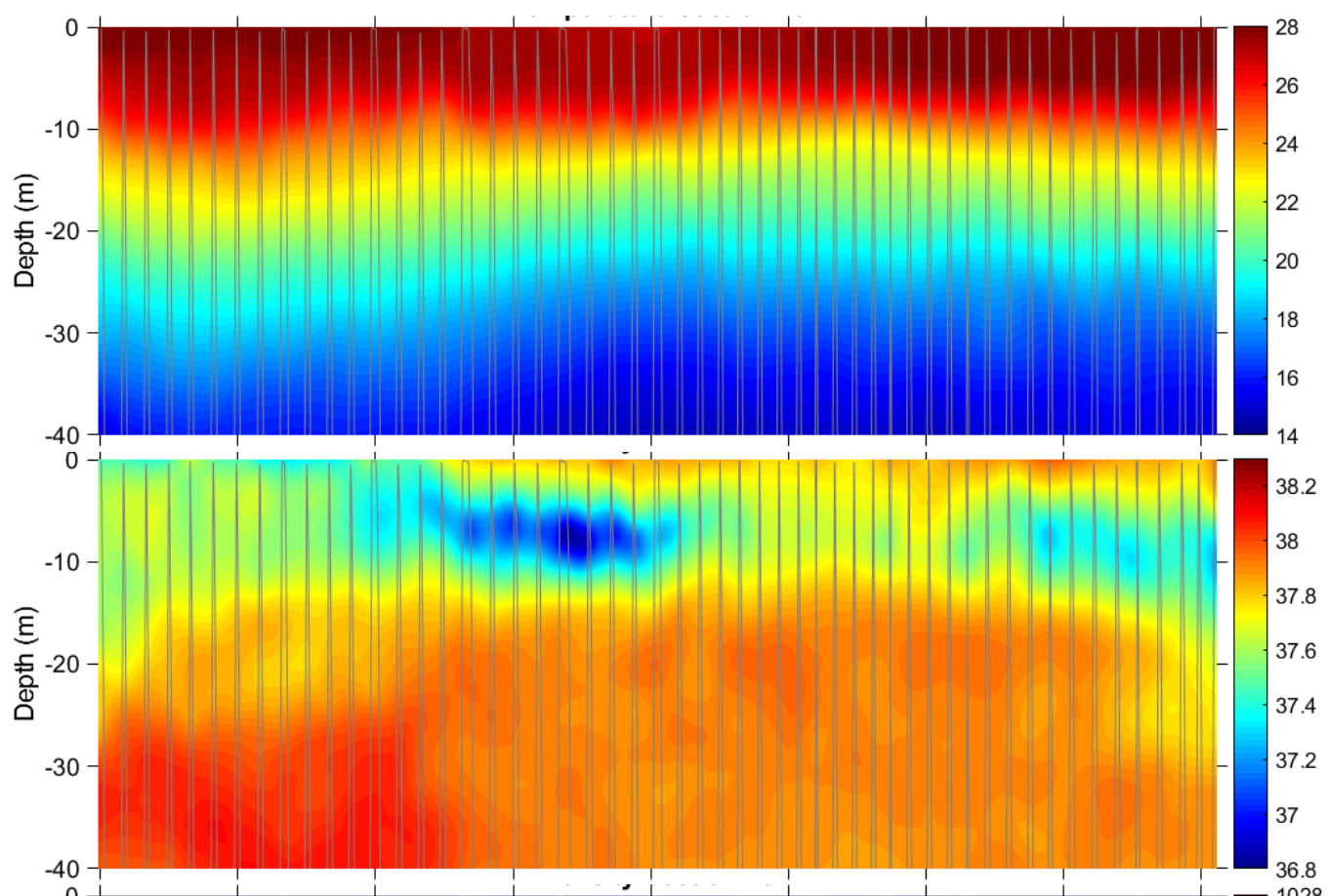

683

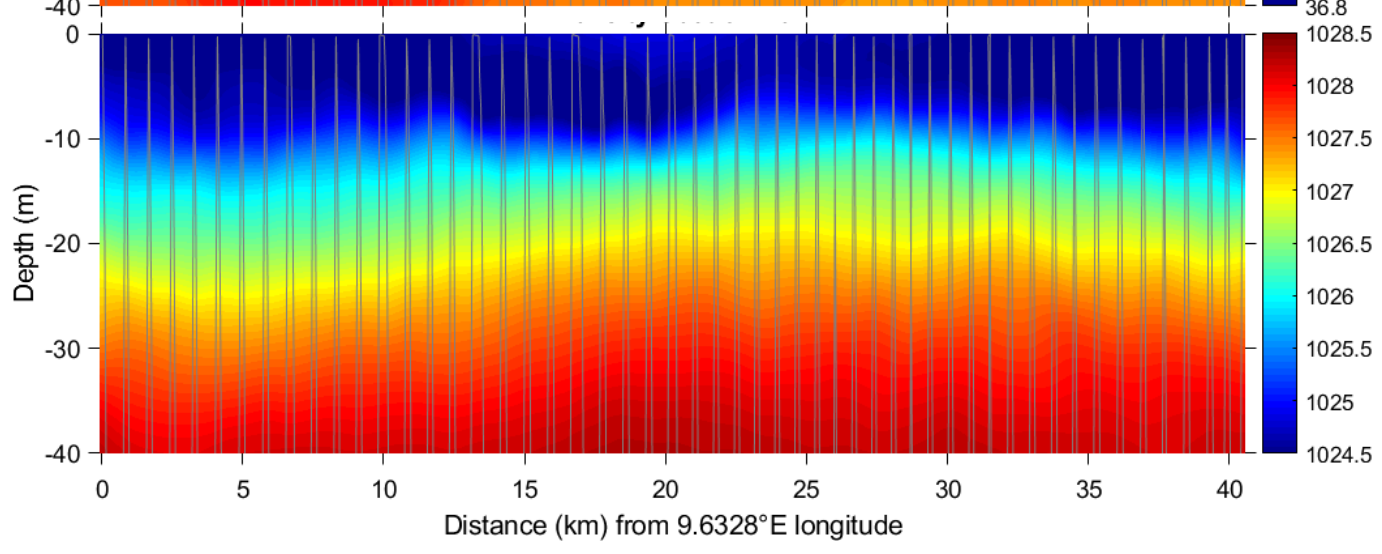

684

685

686

Figure 12. Same as in Figure 10 but for glider transect 15. 


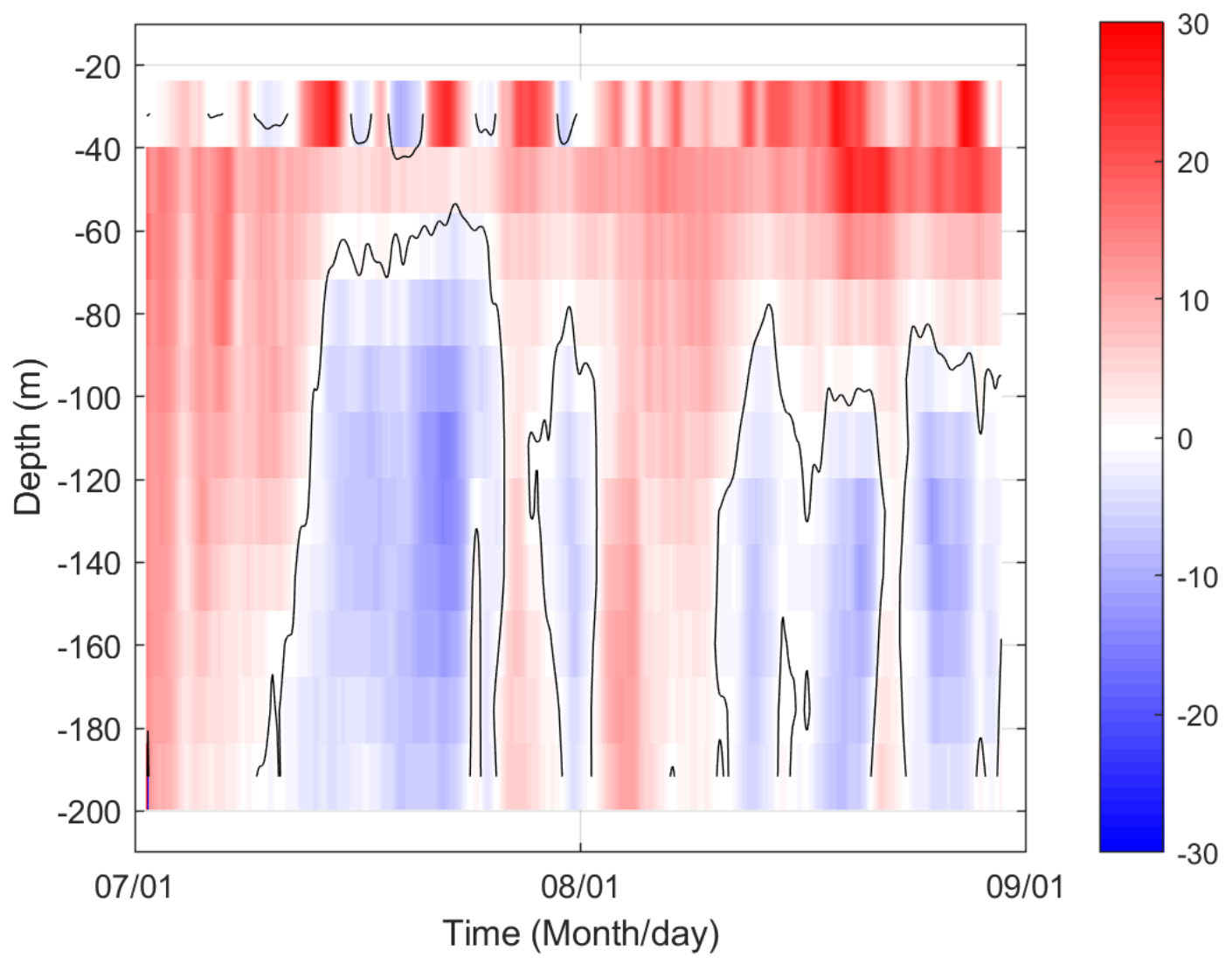

688

689 Figure 13. Meridional velocity $(\mathrm{cm} / \mathrm{s})$ measured by the moored ADCP in the CC (positive 690 northward) as a function of time and depth above $200 \mathrm{~m}$ depth. The uppermost ADCP cell was excluded. The null value is contoured with black curves.

692 
693

694 